\title{
ON THE BOTTLE: HEALTH INFORMATION, ALCOHOL LABELLING AND THE WTO TECHNICAL BARRIERS TO TRADE AGREEMENT
}

\author{
PAULA O’BRIEN*AND ANDREW D MITCHELL ${ }^{* *}$
}

\begin{abstract}
Since 2010, the World Health Organization has advocated the use of health information labelling to inform consumers of the health risks related to alcohol consumption. The alcohol industry oscillates between opposing and supporting alcohol labelling. This article reviews the minutes of the meetings of the World Trade Organization's ('WTO's') Committee on Technical Barriers to Trade ('TBT') (from 2010 to the present day) to garner unique insights into the specific features of alcohol health information labelling that are opposed by the alcohol industry. The article also identifies and analyses the trade law arguments that are made against these contested labelling measures. These arguments primarily come from the WTO's TBT Agreement. Our view is that the TBT Agreement will provide little comfort to alcohol exporting members who seek to rely on it to challenge alcohol health labelling measures, such as those discussed in the TBT Committee.
\end{abstract}

\section{INTRODUCTION}

In 2010, the World Health Organization ('WHO') published the Global Alcohol Strategy to Reduce the Harmful Use of Alcohol ('Global Alcohol Strategy'), with one of its recommendations being the 'labelling [of] alcoholic beverages to indicate... the harm related to alcohol'. ${ }^{1}$ These harms are varied and potentially serious, including acute and chronic health problems for the drinker and others. ${ }^{2}$ Rehm and Shield suggest that alcohol use is causally connected to more than 200 diseases, conditions and injuries, ${ }^{3}$ with at least a further 25 diseases and conditions entirely attributable to alcohol. 'Alcohol dependence syndrome', called 'alcoholism' in the past, has been officially recognised a mental disorder. ${ }^{5}$ As a toxic substance, alcohol consumption can cause alcohol poisoning in the short-term, and cirrhosis, heart disease

\footnotetext{
* LLM (Cantab); BA/LLB(Hons) (Melb). Senior Lecturer, University of Melbourne Law School.

** PhD (Cantab); LLM (Harv); Dip Int Law (Melb); LLB (Melb); BCom (Melb). Professor, University of Melbourne Law School; Future Fellow, Australian Research Council; Director, Global Economic Law Network. This research was supported in part by the Australian Research Council pursuant to the Future Fellowship scheme (project number FT130100416). The authors thank Tania Voon and Robin Room for helpful comments on an earlier draft, and Kyle Dickson-Smith, Pei Xuan Liu, and Sophia Kaiko for their research and editorial assistance. The authors also appreciate the helpful comments provided by the referees.

${ }^{1}$ World Health Organization, Global Strategy to Reduce the Harmful Use of Alcohol, WHA Res 63.13, 63 ${ }^{\text {rd }}$ sess, $8^{\text {th }}$ plen mtg, WHO Doc WHA63/2010/REC/1 (21 May 2010) 17.

2 Stephen S Lim et al, 'A Comparative Risk Assessment of Burden of Disease and Injury Attributable to 67 Risk Factors and Risk Factor Clusters in 21 Regions, 1990-2010: A Systematic Analysis for the Global Burden of Disease Study 2010’ (2012) 380 The Lancet 2223, 2224-2250.

${ }^{3}$ Jürgen Rehm and Kevin D Shield, 'Alcohol and Mortality: Global Alcohol Attributable Deaths from Cancer, Liver Cirrhosis and Injury in 2010’ (2013) 35 Alcohol Research: Current Reviews 174, 174.

${ }^{4}$ Kevin D Shield, Charles Parry and Jürgen Rehm, 'Focus On: Chronic Diseases and Conditions Related to Alcohol Use' (2013) 35 Alcohol Research: Current Reviews 155, 155.

5 Thomas Babor et al, Alcohol: No Ordinary Commodity (Oxford University Press, $2^{\text {nd }}$ ed, 2010) 18.
}

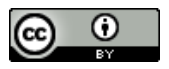

articles are free to use with proper attribution in educational and other non-commercial settings. 
and cancers (in at least seven sites, including the liver, colon and breast) ${ }^{6}$ in the long-term. ${ }^{7}$ With intoxication, human functioning is impaired, ${ }^{8}$ increasing the risk to the drinker of injuries and death through falls, drink driving, violence, and self-harm. ${ }^{9}$ Persons other than the drinker can also be killed or physically or psychologically harmed by another's intoxication as victims of street or family violence, ${ }^{10}$ or drunken driving.

Yet, despite alcohol being considered by some as the most harmful of all drugs, ${ }^{11}$ only 30 of the world's nearly 200 countries have mandated that alcoholic beverage labels bear information and warnings about the harms related to alcohol, ${ }^{12}$ with the majority of these warning schemes in place before the WHO made its recommendation in 2010. It is more common for countries to require other types of 'health information' on alcoholic beverages, such as ingredients lists, or information about caloric, nutritional or alcohol content, or number of standard drinks. ${ }^{13}$ In some instances, governments have not mandated the provision of health information on alcoholic beverage labels but have asked alcohol producers to apply such labels voluntarily, sometimes accompanied by a threat to regulate the industry if it fails to regulate itself. ${ }^{14}$

The alcohol industry position in relation to labels is multi-faceted. On the one hand, it seems it would prefer that its products not bear government-mandated health information. The industry often argues that warnings are not effective to change drinking behaviour, that measures should be targeted at problem drinkers only and not the vast numbers of 'responsible drinkers', that health information labelling is redundant as people already possess the information, and that labelling is an unfair burden on a productive, job-creating industry. ${ }^{15}$ On the other hand, the industry runs its own labelling schemes for health warnings, and caloric and nutritional information, and argues that government regulation is not required because industry selfregulatory schemes are operating so effectively. In fact, the major global alcohol producers have committed to including warnings, including a pictogram, about the risks of drink driving, drinking during pregnancy and under age drinking on their packaging by $2020 .{ }^{16}$

\footnotetext{
${ }^{6}$ Jennie Connor, 'Alcohol Consumption as a Cause of Cancer' (2016) 112 Addiction 222, 223.

${ }^{7}$ Babor, above n 5, 15.

${ }^{8}$ Ibid 17.

${ }^{9}$ Ibid.

${ }^{10}$ See, eg, Jason A Ferris et al, 'The Impacts of Others' Drinking on Mental Health' (2011) 195 Medical Journal of Australia S22, S25-S26.

${ }^{11}$ David J Nutt, Leslie A King and Lawrence D Phillips, 'Drug Harms in the UK: a Multicriteria Decision Analysis' (2010) 376 The Lancet 1558, 1558-1565.

${ }^{12}$ International Alliance for Responsible Drinking, Health Warning Labeling Requirements (April 2016) $<$ http://www.iard.org/policy-tables/health-warning-labeling-requirements/>.

${ }^{13}$ International Alliance for Responsible Drinking, Beverage Alcohol Labeling Requirements (July 2017) $<$ http://www.iard.org/policy-tables/beverage-alcohol-labeling-requirements/ $\geq$.

${ }^{14}$ See, eg, the new EU Commission rule on ingredient and caloric information listings on alcoholic beverages: European Commission, 'Labelling of Alcoholic Beverages: Commission Report Invites the Industry to Submit a Self-Regulatory Proposal' (Press Release, IP/17/551, 13 March 2017) <http://europa.eu/rapid/press-release_IP17-551_en.htm>. Whether governments make good on the threats are another question: see Paula O'Brien, 'The Contest over "Valuable Label Real Estate": Public Health Reforms to the Laws on Alcohol Beverage Labelling in Australia' (2014) 37 University of New South Wales Law Journal 565, 599-600.

${ }^{15}$ See, eg, Australian Alcoholic Beverage Industries, Submission to the Secretariat on Alcoholic Beverages, Review of Food Labelling Law and Policy, 5 September 2011, $2, \quad 10$ $<$ http://www.wfa.org.au/assets/submissions/pdfs/2011/Blewett_Review_submission.pdf $>$.

${ }^{16}$ Beer Wine Spirits, Providing Consumer Information and Responsible Product Innovation (2016) Producers' Commitments <http://www.producerscommitments.org/commitments/providing-consumer-information-andresponsible-product-innovation/>.
} 
Where governments mandate or propose to mandate health information on alcohol labels, we are also seeing the industry raising international trade law arguments against such information, which, regardless of their merit, have the potential to deter governments from taking public health measures. ${ }^{17}$ This is evident in the activities of the World Trade Organization's ('WTO's') Committee on Technical Barriers to Trade ('TBT Committee') created pursuant to the Agreement on Technical Barriers to Trade ('TBT Agreement'). ${ }^{18}$ Since the publication of the Global Alcohol Strategy in 2010, alcohol labelling proposals have been the most recurring alcohol control measure on the agenda of the TBT Committee, with the major wine and/or spirits exporters, such as the European Union, the United States, Chile, Mexico, Australia, and New Zealand repeatedly raising questions about other members' alcohol labelling proposals. In this article, we examine the discussions about alcohol labelling measures as recorded in the minutes of TBT Committee meetings. Our examination is for two purposes: (1) to determine which labelling proposals, or more specifically, which aspects of these proposals are concerning to alcohol exporting members and, arguably, alcohol exporters themselves; and (2) to understand the arguments based on trade law that are made against such labelling proposals. The TBT Committee minutes are a unique source of insight into exporting nations and their alcohol industries' objections to alcohol health labelling. Although the TBT Committee is a forum for WTO members only, we consider that the interests being represented by 'objecting' members in that Committee are representative of, or at least highly indicative of the position of the alcohol and related industries. Health interests are noticeably absent. It is difficult to discern the features of alcohol labelling that are most troubling to alcohol industry interests, so clearly and specifically in any other forum.

In Part II, we commence by examining the threat that alcohol health information labelling potentially poses to the alcohol (and related) industries, especially in countries with major alcohol export industries. This Part includes a discussion of the public health evidence about alcohol labelling. In Part III, we identify the labelling proposals that have been subject to discussion in the TBT Committee and determine the features of the proposals that have been most contentious. We also identify the trade law arguments that WTO members make about these alcohol labelling proposals. These arguments are mainly framed in terms of the TBT Agreement. In Part IV, we examine some of the critical legal and evidentiary issues raised by the main trade law arguments being used in the TBT Committee meetings against alcohol health labelling. Our focus is on Articles 2.2 and 2.4 of the TBT Agreement. In Part V, we conclude and offer some final comments and cautions about future international efforts in relation to alcohol health labelling standards.

\section{The Threat of AlCohol HeAlth INFORMATION LABELLING}

Why would be the alcohol industry and major exporting countries be so concerned about health information labelling as a policy intervention to prevent alcohol-related harm? There has been relatively low adoption of alcohol labelling policies and there seem to be very few governments considering introducing labelling reforms. Further, the only studies conducted on existing alcohol warning labelling schemes indicate that they have not been effective in reducing consumption and, at most, they have changed 'intervening variables', such as having more conversations about risks related to drinking, having intentions to change drinking habits, or

\footnotetext{
${ }^{17}$ See Jonathan Liberman and Andrew Mitchell, 'In Search of Coherence between Trade and Health: Interinstitutional Opportunities’ (2010) 25 Maryland Journal of International Law 143, 165.

${ }^{18}$ Agreement on Technical Barriers to Trade ('TBT Agreement'), opened for signature on 15 April 1994, 1868 UNTS 120 (entered into force 1 January 1995) (annex 1A of Marrakesh Agreement Establishing the World Trade Organization, opened for signature 15 April 1994, 1867 UNTS 3).
} 
taking action to deter another person from driving when intoxicated. ${ }^{19}$ The findings come from studies of the United States' warning label scheme, which has been in place since 1989 and is one of the most long-standing alcohol warnings. It is a text-only warning that states: 'GOVERNMENT WARNING: (1) According to the Surgeon General, women should not drink alcoholic beverages during pregnancy because of the risk of birth defects. (2) Consumption of alcoholic beverages impairs your ability to drive a car or operate machinery, and may cause health problems' ${ }^{20}$ There are some basic presentation requirements set for these warnings, including that it appear on a contrasting background and meet minimal legibility requirements. ${ }^{21}$ There have been no changes to the text of the label since it was introduced. No other alcohol warning labelling regimes have been studied. There are also no studies that show the effects of other alcohol health information labelling, such as energy content information and ingredients lists. ${ }^{22}$

Despite the comparatively weak evidence base and the relative lack of government interest to date in alcohol labelling, alcohol, and especially wine and spirits, are major export commodities. The world wine trade was valued at a $€ 29$ billion in $2016,{ }^{23}$ with about 104 billion hectolitres of wine (or one third of all wine produced) entering international markets. ${ }^{24}$ In 2015, Spain, Italy and France were the largest exporters, by a considerable margin, together producing 56 per cent of all wine in the global market. Chile followed, producing 8.1 per cent of exported wine, Australia 7.0 per cent, South Africa 4.2 per cent, the US 4.0 per cent, Germany 3.9 per cent, Portugal 2.8 per cent, Argentina 2.6 per cent, and New Zealand 1.9 per cent. ${ }^{25}$ The global spirits industry was forecast in 2010 to be worth about US $\$ 22$ billion, with the United Kingdom and France (both then part of the European Union) producing 50 per cent of all exported spirits. ${ }^{26}$ For obvious reasons, the alcohol industry, and the major wine and spirits exporters, would not want to see the introduction of any policy, including labelling, that would cause overall alcohol consumption to fall.

For these exporters, the developing evidence base about alcohol labelling is likely a further source of concern. Although the evidence from existing labelling schemes, discussed above, is not strong, new studies based on prototype alcohol health information labels ${ }^{27}$ supported by

\footnotetext{
${ }^{19}$ For a review of all the evidence, see Paula O'Brien et al, 'Marginalising Health Information: Implications of the Trans-Pacific Partnership for Alcohol Labelling' (2017) 41 Melbourne University Law Review 341 ('Marginalising Health Information'); Claire Wilkinson and Robin Room, 'Warnings on Alcohol Containers and Advertisements: International Experience and Evidence on Effects' (2009) 28 Drug and Alcohol Review 426, 436; Tammy W Tam and Thomas K Greenfield, ‘Do Alcohol Warning Labels Influence Men's and Women's Attempts to Deter Others from Driving When Intoxicated?' (2010) 20 Human Factors and Ergonomics in Manufacturing \& Service Industries 538, 543-4.

${ }^{20}$ Alcohol, Tobacco Products and Firearms, 27 CFR $\S 16.21$ (1998).

${ }^{21}$ Ibid $\S 16.22$.

${ }^{22}$ O’Brien et al, 'Marginalising Health Information', above n 19, 343.

${ }^{23}$ International Organisation of Vine and Wine, 2017 World Vitiviniculture Situation: OIV Statistical Report on World Vitiviniculture, (2017) 15-17.

${ }^{24}$ Ibid.

${ }^{25}$ Organisation International de la Vigne et du Vin [International Organisation of Vine and Wine], State of the Vitiviniculture World Market: April 2016 (2016) 11.

${ }^{26}$ Global Spirits Manufacturing: C1122-GL: IbisWorld Industry Report (IbisWorld, 2010) 15.

${ }^{27}$ Kate Vallance et al, "We Have a Right to Know": Exploring Consumer Opinions on Content, Design and Acceptability of Enhanced Alcohol Labels' (2018) 53 Alcohol and Alcoholism 20; Eric Hobin et al, 'Testing the Efficacy of Alcohol Labels with Standard Drink Information and National Drinking Guidelines and Consumers' Ability to Estimate Alcohol Consumption' (2018) 53 Alcohol and Alcoholism 3; Emma R Miller et al, 'Message on a Bottle: Are Alcohol Warning Labels About Cancer Appropriate?' (2016) 16 BMC Public Health 139, 142; Simone Pettigrew et al, 'The Effect of Cancer Warning Statements on Alcohol Consumption Intentions' (2016)
} 
studies of existing tobacco warning labels ${ }^{28}$ indicate that alcohol health warnings may be effective if they adopt features more similar to those used for tobacco warning labels in countries like Australia. ${ }^{29}$ The emerging evidence indicates that prominent, front of container labels, with rotating graphic and text 'messages that are specific and detailed, containing statistics ${ }^{30}$ may be more effective in shifting consumption patterns than existing label schemes. ${ }^{31}$ There is a further body of supporting evidence that demonstrates the ineffectiveness of voluntary industry labelling schemes, which tend not to bear the features, shown increasingly in the prototype studies, to have impact. ${ }^{32}$

Further, it may be the potential of the label to change the 'cultural conversation' about alcohol that the industry fears more than changes in behaviour. If striking warnings about the negative impacts of alcohol consumption take over the label space, alcohol no longer looks like an 'ordinary commodity'. ${ }^{33}$ It becomes marked out as a product that is potentially dangerous, and the industry's messages about alcohol as '[p]art of everyday life, especially for the affluent and powerful (compared to smoking tobacco or being overweight) ${ }^{34}$ potentially become much less persuasive. Changing the 'information environment' in which the product exists may also lead to shifts in public opinion about the acceptability of government interventions to reduce harms from alcohol. This concern about the label's expressive function may be heightened in relation to emerging alcohol markets, where consumer demand for commercial alcohol is not yet entrenched, is in the process of being created through the alcohol industry's promotional activity, ${ }^{35}$ and could be unsettled by contrary public health messages.

The alcohol industry is also generally opposed to population-level measures, like labelling, taxation, marketing restrictions, and limitations on availability, that apply to all drinkers and not just 'problem' drinkers. ${ }^{36}$ Arguably, health information labelling is also directed at nondrinkers, informing them about the risks of their own potential drinking or the drinking of those around them. The industry view is that most consumers drink responsibly and that interventions should largely leave those people alone (except for the occasional educational message). It is those who fail to drink 'properly' ${ }^{37}$ who should be targeted, with the preferred interventions

31 Health Education Research 60, 64; Simone Pettigrew et al, 'Developing Cancer Warning Statements for Alcoholic Beverages' (2014) 14 BMC Public Health 1, 3.

${ }^{28}$ Seth M Noar et al, 'Pictorial Cigarette Pack Warnings: A Meta-analysis of Experimental Studies' (2016) 25 Tobacco Control 341, 346; Michelle Scollo, 'Attachment 12.1 Health Warnings: A12.1.4 What Makes an Effective Health Warning?' in Michelle M Scollo and Margaret H Winstanley (eds), Tobacco in Australia: Facts and Issues (Cancer Council Victoria, $4^{\text {th }}$ ed, 2012) <https://perma.cc/2XRT-H758>; David Hammond, 'Health Warning Messages on Tobacco Products: A Review’ (2011) 20 Tobacco Control 327, 327.

${ }^{29}$ O'Brien et al, 'Marginalising Health Information', above n 19, 366.

${ }^{30}$ Ibid 364.

${ }^{31}$ See also AER Foundation, 'Alcohol Product Labelling: Health Warning Labels and Consumer Information' (Policy Position Paper, 16 August 2011) $3<$ https://perma.cc/B4X4-6CAW>.

${ }^{32}$ See, eg, Kerri Coomber et al, 'Do Consumers "Get the Facts"? A Survey of Alcohol Warning Label Recognition in Australia' (2015) 15 BMC Public Health 816.

${ }^{33}$ Babor, above n 5, 2.

${ }^{34}$ Robin Room, Jürgen Rehm and Charles Parry, 'Alcohol and Non-communicable Diseases: Time for a Serious International Public Health Effort' (2011) 106 Addiction 1547, 1547.

${ }^{35}$ See, eg, David Jernigan, 'The Global Expansion of Alcohol Marketing: Illustrative Case Studies and Recommendations for Action' (1999) 20 Journal of Public Health Policy 56.

${ }^{36}$ Global Strategy to Reduce the Harmful Use of Alcohol, above n 1, 14-17.

${ }^{37}$ DrinkWise, Drinking — Do It Properly (2017) <https://drinkwise.org.au/our-work/drinking-do-it-properly/\#>. 
being 'medical intervention', or criminal penalties for drink driving or harms caused when intoxicated. ${ }^{38}$

The current public health approach does not reject individual measures. Rather, it advocates the use of population controls in conjunction with interventions for those with problematic alcohol consumption. From a public health perspective, population measures aimed at reducing consumption across the entire population are important for several reasons. One is the need to avoid the stigmatization of (sometimes) vulnerable individuals through measures targeted at problem drinkers, such as criminalization and institutionalization. ${ }^{39}$ The other highly contentious reason is found in the seminal work of Bruun et al from the 1970s (and the body of research that their work has influenced) that 'the higher the average amount of alcohol consumed in society, the greater incidence of problems experienced by that society'. ${ }^{40}$ This concept rests on two other claims: firstly, that moderate drinkers as a group, because of its size compared to the group of heavy drinkers, experience the greatest amount of alcohol-related harm; ${ }^{41}$ and secondly, that consumption levels shift in concert across groups of light, heavier and heaviest drinkers. ${ }^{42}$ The alcohol industry vehemently resists Bruun et al's theory and its implications that population control measures are needed to reduce alcohol consumption across the entire society in order reduce harms from alcohol. As population measures generally require government intervention, this is a further reason for industry to resist them.

Finally, the alcohol industry likely has concerns that the strong regulatory approaches to tobacco control, that have gained traction in the large Western economies in the last 40 years, will influence the treatment of alcohol. The products are different in various respects, including the mechanisms and pathways by which they cause harm. Tobacco also now occupies a very different cultural place from alcohol, in Western societies,${ }^{43}$ but that cultural meaning has been shifted, including through the government regulation of the product. Further, some of the successful regulatory interventions used to reduce smoking and its uptake have potential application to alcohol. These are interventions that have been 'layered' on top of each other over several years, with the cumulative effect of the measures being the significant reduction in rates of smoking in many countries.

In Australia, for example, from the time tobacco health warnings were first introduced in 1973 to the commencement of the plain packaging laws in 2012, there has been a multitude of incremental regulatory interventions in the form of warnings, marketing restrictions, taxation

\footnotetext{
${ }^{38}$ See, eg, Australian Alcoholic Beverage Industries, Review of Food Labelling Law and Policy, above n 15, 269; cf Julia Quilter 'The Thomas Kelly Case: Why a "One Punch" Law is Not the Answer' (2014) 38 Criminal Law Journal 16.

${ }^{39}$ Christoffer Tigerstedt, 'Alcohol Policy, Public Health and Kettil Bruun' (1999) 26 Contemporary Drug Problems 209, 218-223.

${ }^{40}$ Babor, above n 5, 5; Kettil Bruun et al, Alcohol Control Policies in Public Health Perspective (Finnish Foundation for Alcohol Studies, 1975) 12. This theory goes by various names, including the 'single-distribution theory', the 'distribution of consumption' theory, the 'constant proportion' theory, and the 'neo-prohibitionist theory': see Robin Room, 'Alcohol Control and Public Health' (1984) 5 Annual Review of Public Health 293, 303.

${ }^{41}$ This phenomenon has been referred to as the 'prevention paradox': Babor, above n 5, 16. See also Tim Stockwell et al, 'Unravelling the Preventative Paradox for Acute Alcohol Problems' (1996) 15 Drug and Alcohol Review 7, 8.

42 Babor, above n 5, 30 .

${ }^{43}$ See Klaus Mäkelä, 'The Uses of Alcohol and Their Cultural Regulation' (1983) 26 Acta Sociologica 21, 24; R Room and K Mäkelä, 'Typologies of the Cultural Position of Drinking' (2000) 61 Journal of Studies on Alcohol and Drugs 475, 481 .
} 
increases, and bans on smoking in public places. ${ }^{44}$ For the alcohol industry, resisting the introduction of government-mandated labelling (or any one of the population level interventions) is likely important to avoid the potential for alcohol regulation to follow a similar path to tobacco, with the addition of each policy seemingly paving the way for further and more radical interventions in the future. With alcohol, calls for higher taxation and more restrictions on alcohol marketing have been common since the 1970s and are found in the Global Alcohol Strategy, ${ }^{45}$ but calls for plain packaging of alcohol have also emerged recently, with the UK government's public health agency putting it on the agenda for consideration. ${ }^{46}$

\section{CURRENT Trade IsSUES IN ALCOHOL LABELLING REGUlATION}

In this Part, we review the alcohol labelling matters that have come before the WTO TBT Committee as 'specific trade concerns' between 2010, when the Global Alcohol Strategy was launched, and 2017, and identify the features of these measures that have been most contested by WTO members. Although the TBT Committee is only open to member states and a limited number of official observers, and is not open to commercial actors, ${ }^{47}$ we are of the view that the specific trade concerns about alcohol labelling raised in this Committee can be considered to be reflective, or indicative, of the position of the alcohol industries in those jurisdictions. In some instances, the member state position may have been informed by consultations with key segments of the alcohol industry on the specific matter before the Committee. In other instances, the member state may advance a position that it understands to be consonant with the industry's general concerns about increased regulation of alcohol labelling.

In Part A, we introduce the TBT Agreement and its notification obligations, and the TBT Committee and its processes for members to discuss 'specific trade concerns'. In Part B, we briefly outline all of the new alcohol labelling proposals that have been discussed in the Committee. The purpose of this Part is to give some sense of the developments in alcohol labelling around the world. With this broad sweep of labelling policies as background, in Part $\mathrm{C}$, we then: (1) determine the features of these policies to which members seemed to be the most resistant; and (2) identify the trade law arguments that members have made in relation these labelling measures and that might be put forward, should a dispute about one of the measures arise in the WTO.

\footnotetext{
44 Department of Health (Aust), Tobacco Control Key Facts and Figures (29 June 2016) $<$ http://www.health.gov.au/internet/main/publishing.nsf/content/tobacco-kff $>$.

${ }^{45}$ See Bruun et al, above n 40, 12; Global Alcohol Strategy, above n 1, 14-17.

${ }^{46}$ Public Health England, 'The Public Health Burden of Alcohol and the Effectiveness and Cost-Effectiveness of Alcohol Control Policies: An Evidence Review' (2016) 138-9.

${ }^{47}$ World Trade Organization, International Intergovernmental Organizations Granted Observer Status to WTO Bodies $(2018)<\mathrm{https}$ ://www.wto.org/english/thewto_e/igo_obs_e.htm\#tbt>.
} 


\section{A The TBT Committee}

Our focus in this article is on the TBT Agreement and its related Committee, because this is the WTO Agreement which is most relevant to trade concerns about product labelling, and the TBT Committee is the WTO forum most commonly used to ventilate concerns about alcohol labelling. ${ }^{48}$ The TBT Agreement is concerned to address 'regulatory protectionism' ${ }^{49}$ by ensuring that certain 'behind the border' measures, in particular what the TBT Agreement calls 'technical regulations', 'standards', and 'procedures for assessment of conformity', do not create unnecessary obstacles to international trade ${ }^{50}$ and are non-discriminatory. ${ }^{51}$ At the same time, the TBT Agreement recognises the regulatory autonomy of members, including for the protection of human life or health, ${ }^{52}$ by only prohibiting protectionist regulations and not requiring 'positive integration' or full harmonization of members' regulatory systems. That said, there is encouragement for members to create and follow common international standards. ${ }^{53}$ The scope of the TBT Agreement (including the meaning of the concept 'technical regulation') and several of the principal substantive obligations of the TBT Agreement are discussed in more detail in Part IV.

Several procedural requirements that are key to the operation of the TBT Agreement are the notification obligation in articles 2.9 to $2.11 .^{54}$ Article 2.9. requires members to notify the WTO Secretariat where it proposes a technical regulation (1) that departs from an applicable international standard for such a measure, or where such a standard does not exist; and (2) the technical regulation may have a significant effect on the trade of other members. ${ }^{55}$ It also requires notifying members to provide the draft technical regulation to other members on request, and to allow ample time to receive and take into account comments from other members. ${ }^{56}$ Article 2.11 further requires that members publish, in a manner that allows other members to 'become acquainted with them', all technical regulations that they have adopted. ${ }^{57}$ It is through these centralised notification mechanisms that members become aware of developments in other member jurisdictions. ${ }^{58}$

\footnotetext{
${ }^{48}$ Other relevant WTO rules include those on non-discrimination in the treatment of goods and those relating to the protection of intellectual property rights: see respectively: General Agreement on Tariffs and Trade 1994, art III(4), signed 30 October 1947, LT/UR/A-1A/1/GATT/2 (entered into force 1 January 1995) (annex 1A of Marrakesh Agreement Establishing the World Trade Organization, opened for signature 15 April 1994, 1867 UNTS 3); Agreement on the Trade-Related Aspects of Intellectual Property Rights' (entered into force 1 January 1995) (annex 1C of Marrakesh Agreement. International investment law is also potentially pertinent: see eg, Agreement Between the Swiss Confederation and the Oriental Republic of Uruguay on the Reciprocal Promotion and Protection of Investments, Switzerland and Uruguay, signed 7 October 1988, 1976 UNTS 389 (entered into force 22 April 1991) arts 3(1), 3(2), 5, 11. These were the provisions that were the basis of Philip Morris's challenge to Uruguay's tobacco labelling laws: see Philip Morris Brands Sàrl v Uruguay (Award) (ICSID, Arbitral Tribunal, Case No ARB/10/7, 8 July 2016) [12].

${ }^{49}$ Robert Howse, 'Introduction' in Tracey Epps and Michael J Trebilcock (eds), Research Handbook on the WTO and Technical Barriers to Trade (Edward Elgar, 2013) 1, 2.

${ }^{50}$ TBT Agreement, above n 18, art 2.2.

${ }^{51}$ Ibid art 2.1.

52 Ibid Preamble 6.

${ }^{53}$ Ibid art 2.4.

${ }^{54}$ Ibid arts 2.9-2.11.

${ }^{55}$ Ibid arts 2.9.1, 2.9.2. Article 2.10 makes similar provision but with special arrangements for urgent measures to address circumstances such as public health and safety emergencies.

${ }^{56}$ Ibid arts 2.9.3, 2.9.4.

${ }^{57}$ Ibid art 2.11.

${ }^{58}$ Ibid art 10.3, which sets a requirement that each member create an 'enquiry point' that can answer questions and provide information to other members or 'interested parties' which would include industry.
} 
Where a technical regulation proposed or adopted in another country is of concern to a WTO member, it has the option of raising the matter for discussion in the TBT Committee. The members could, of course, engage in discussions bilaterally or multilaterally, but it appears they have seen increasing value in raising 'specific trade concerns' ('STCs') in the TBT Committee. ${ }^{59}$ The TBT Committee is not a complaints body, but provides members (and official observers) ${ }^{60}$ with 'the opportunity of consulting on any matters relating to the operation of [the TBT] Agreement or the furtherance of its objectives' ${ }^{61}$ In 2010 , the Committee developed a mechanism for members to raise and deal with STCs, ${ }^{62}$ with many of these relating to notified measures. ${ }^{63}$ Through this mechanism, members ask questions, request information and make comments about the measure in questions. But, as can be expected of a consultative forum such as this one, concerns are often not expressed in terms of specific provisions in the WTO Agreements. There are often also requests such as for translations of notifications, further time for comment and implementation, and information about timelines for adoption and implementation.

Through the STC facility, it is argued by Horn, Mavroidis and Wijkström that 'trading partners acquire more complete knowledge about each other's measures coming under the purview of the TBT Agreement, and are in [a] better position to determine whether to raise a dispute before the WTO dispute settlement system'. ${ }^{64}$ These same authors claim that the TBT Committee is 'akin to an informal form of resolution of trade conflicts', ${ }^{65}$ serving to 'settle' trade concerns between members, ${ }^{66}$ without resort to formal WTO dispute settlement. The WTO dispute settlement system engages the parties in formal consultations and, if the matter remains unresolved, adjudication before a Panel and, ultimately, the Appellate Body. ${ }^{67}$ It is suggested that through the more informal TBT Committee processes, members will revise their measures to make them (more) TBT-consistent, complaining members may produce offers of technical

\footnotetext{
${ }^{59}$ See Petros C Mavroidis and Erik N Wijkström, 'Moving Out of the Shadows: Bringing Transparency to Standards and Regulations in the WTO's TBT Committee' in Tracey Epps and Michael J Trebilcock (eds), Research Handbook on the WTO and Technical Barriers to Trade (Edward Elgar, 2013) 204.

${ }^{60}$ See International Intergovernmental Organizations Granted Observer Status to WTO Bodies, above n 47.

${ }^{61}$ TBT Agreement, above n 18.

${ }^{62}$ Committee on Technical Barriers to Trade, Decisions and Recommendations Adopted by the WTO Committee on Technical Barriers to Trade Since 1 January 1995, WTO Doc G/TBT/1/Rev.10 (9 June 2011) 43.

${ }^{63}$ Denise Prévost, 'Transparency Obligations Under the TBT Agreement' in Tracey Epps and Michael J Trebilcock (eds), Research Handbook on the WTO and Technical Barriers to Trade (Edward Elgar, 2013) 128, 158.

${ }^{64}$ Henrik Horn, Petros C Mavroidis and Erik Wijkström, 'Between Transparency and Adjudication: Environmental Measures in the WTO TBT Committee' (Working Paper, ENTWINED, 28 February 2012) $<$ http://www.econ-law.se/Papers/TBT\%2028Feb2012-2.pdf $>$. No alcohol labelling measures have been taken to WTO dispute settlement. However, alcohol has been the subject of several WTO disputes, including in relation to alcohol taxation: see Appellate Body Reports, Japan - Taxes on Alcoholic Beverages, WTO Doc WT/DS8/AB/R, WT/DS10/AB/R, WT/DS11/AB/R (4 October 1996). The WTO's dispute settlement system is also currently in use in relation to Canada's rules on the sale of wine. Several countries, including the US, Australia, New Zealand and Argentina have made requests for consultations to Canada: see eg, Canada Measures Governing the Sale of Wine in Grocery Stores, WTO Doc WT/DS520/5 (23 February 2017) (Request for Consultations by the United States).

${ }^{65}$ Henrik Horn, Petros C Mavroidis and Erik N Wijkström, 'In the Shadow of the DSU: Addressing Specific Trade Concerns in the WTO SPS and TBT Committees' (Working Paper No 960, Research Institute of Industrial Economics, 2013) $1<$ https://www.econstor.eu/bitstream/10419/81444/1/wp960.pdf>.

${ }^{66}$ Ibid 29.

${ }^{67}$ Marrakesh Agreement Establishing the World Trade Organization, opened for signature 15 April 1994, 1867 UNTS 3 (entered into force 1 January 1995) annex 2 ('Understanding on Rules and Procedures Governing the Settlement of Disputes').
} 
or financial assistance to 'facilitate compliance', ${ }^{68}$ or complaining members may also come to some level of acceptance of the proposed measures.

\section{B Alcohol Labelling Matters Before the TBT Committee}

Since 2010, there have been 14 alcohol labelling notifications under consideration as specific trade concerns in the TBT Committee. ${ }^{69}$ In nine of these notifications, health warnings for alcoholic beverages have been proposed. The rationale offered by members for each of these labelling measures fits within the 'protection of human life and health' objective articulated in the Preamble to the TBT Agreement. ${ }^{70}$ These warnings are discussed below in section 1 in chronological order. Seven notifications have included other alcohol labelling matters. These are discussed in section 2. Some notifications have included both warnings and other labelling requirements. The purpose of our review in this section is to show the full set of labelling proposals that we have analysed in order to deduce the particular labelling features that are most objectionable to alcohol interests. This review gives some indication of the different directions in which countries are moving with alcohol labelling policies.

The health warning proposals include a set of highly contentious graphic and text warning labels proposed by Thailand in $2010,{ }^{71}$ which have not been adopted and seem to have been abandoned (at least in their original form). ${ }^{72}$ This labelling proposal represents the high water mark in public health information on alcoholic beverages. The labels were intended to cover 30-50 per cent of the container's surface and to include one of six warnings that were to be rotated every 1000 units of production. One version of the warnings stated: 'drinking alcohol causes liver cirrhosis', 'drinking alcohol leads to unconsciousness and even death', 'drinking alcohol leads to inferior sexual performance', 'drinking alcohol is a bad influence on children and young people'. ${ }^{73}$ Another translation of the labels referred to the same harms but inserted

\footnotetext{
${ }^{68}$ Prévost, above n 63, 158.

${ }^{69}$ There is a further notification which may include alcohol labelling provisions, but it has not been possible to verify the contents of the measure. The Russian Federation has proposed a measure 'to establish uniform requirements for the commercial turnover of alcoholic products'. These requirements seem to include an expiration date for alcoholic beverages but it is not clear from the notified documents and the TBT Committee Minutes whether the expiration date is to be shown on the label: see Committee on Technical Barriers to Trade ('TBT Committee'), Notification - Russia, UN Doc G/TBT/N/RUS/2 (21 December 2012).

${ }^{70}$ TBT Agreement above n 18, Preamble 6. See eg, Turkey's claim that its measure is 'to protect unborn children and minors and to prevent driving under the influence of alcohol': TBT Committee, Notification - Turkey, WTO Doc G/TBT/N/TUR/41 (6 August 2013).

${ }^{71}$ Paula O'Brien, 'Australia's Double Standard on Thailand's Alcohol Warning Labels' (2013) 32 Drug and Alcohol Review 5, 5.

72 Alan Adcock, Aaron Le Marquer and Lennard Meulens, Thailand's Increasingly Stringent Regulatory Controls on the Packaging and Labeling of Alcoholic Beverages (28 August 2015) Tilleke \& Gibbons $<$ http://www.tilleke.com/resources/thailands-increasingly-stringent-regulatory-controls-packaging-and-labelingalcoholic-beve $>$. The EU and NZ have continued to ask Thailand in the TBT Committee for updates about the scheme: Committee on Technical Barriers to Trade, Minutes of the Meeting of 10-11 November 2016, WTO Doc G/TBT/M/70 (17 February 2017) [2.151] (EU), [2.153] (NZ) ('TBT Committee, Minutes'). Thailand committed to notifying the TBT Committee if a regulation on warnings were to be drafted: WTO Doc G/TBT/M/70, [2.156] (Thailand).

${ }^{73}$ TBT Committee, Notification - Thailand, WTO Doc G/TBT/N/THA/332 (21 January 2010); TBT Committee, Notification Addendum - Thailand, WTO Doc G/TBT/N/THA/332/Add.1 (21 January 2010). We have made minor revisions to the English used in the original translation. Paras 3-4 of the Notification state: 'Pictorial labels shall be provided with the warning statements on the harm of alcohol wherein the picture shall be printed in 4 colors and 6 types' and 'The publication of pictorial labels/warning statements under Clause 3 is specified as
} 
the word 'could' into each of the warnings, such as 'drinking alcohol could cause liver cirrhosis." $^{\text {" }} 4$

In 2011, Kenya notified the WTO of various proposed alcohol control measures, including mandatory health warnings, ${ }^{75}$ which were subject to TBT Committee discussion over several years. These warnings have now come into operation and require that each alcoholic beverage container bear at least two of the following text warnings, covering 30 per cent of the surface area of the package: 'excessive alcohol consumption is harmful to your health', 'excessive alcohol consumption can cause liver cirrhosis', 'excessive alcohol consumption impairs your judgment; do not drive or operate machinery'; and 'not for sale to persons under 18 years' ${ }^{76}$ In 2012 and 2013, Israel and Mexico both proposed and introduced 'two-level' warnings (although the final forms of the labels were slightly changed from the proposals). Israel required alcoholic beverages under 15.5 per cent alc/vol to bear the information 'this product contains alcohol and excessive drinking should be avoided', and products with alcohol content above 15.5 per cent alc/vol to include the information 'excessive alcohol consumption risks lives and is harmful to health'. ${ }^{77}$ Mexico passed a law requiring different text and pictogram labels by reference to the alcohol content of the product, including warnings about drinking and pregnancy, driving, and under-age use. ${ }^{78}$

In 2013, Turkey proposed a new labelling law to include pictograms concerned with drinking and pregnancy, drinking and driving, and under-age drinking, as well as the text, 'Alcohol is not your friend'. The warnings were subject to specific design rules as to font size, style and presentation, which were amended somewhat over the course of several TBT Committee meetings. ${ }^{79}$

South Africa has mandated health warnings on alcoholic beverages since 2007, but, in 2014, it proposed requiring that the warning take up one-eighth of the container and that each of the seven warnings set by government be rotated with equal regularity within 12 months. ${ }^{80}$ These

follows: (1) If the package is in rectangular shape, the space shall not be less than 50 percent of the space of each side with the maximum space or the front and the back side of the package, or not less than 30 percent of the total area of the package if the package is in round or cylinder shape. (2) If the package is of [an]other shape than as specified above, the warning statements shall cover ... no less than 30 percent of the total surface area of the package. To conform with the label requirements, the manufacturers or importers of alcohol beverages shall provide the labels as well as adjust the size of statements from the template stipulated by Office of the Alcohol Control Committee, Ministry of Public Health.' For a copy of the label images, see European Alcohol Policy Alliance, Thailand Notifies WTO Members of Plans to Introduce Alcohol Warning Labels (25 March 2010) $<$ http://www.eurocare.org/library/updates/thailand_notifies_wto_members_of_plans_to_introduce_alcohol_war ning_labels>.

${ }^{74}$ Thaksaphon Thamarangsi and A Puangsuwan, 'Why Thailand Should Have the Pictorial Warning Label on Alcoholic Beverage Packages' (Technical Report, Centre for Alcohol Studies and International Health Policy Program, Thailand, June 2010).

75 TBT Committee, Notification - Kenya, WTO Doc G/TBT/N/KEN/282 (1 March 2011).

${ }^{76}$ The Alcoholic Drinks Control Act 2010 (Kenya) s 32, sch 2.

77 TBT Committee, Notification - Israel, WTO Doc G/TBT/N/ISR/609 (17 July 2012). See also Restriction on Advertisement and Distribution of Alcoholic Beverages Law, Law 5772-2012 (Israel) 23 January 2012.

${ }^{78}$ TBT Committee, Notification - Mexico, WTO Doc G/TBT/N/MEX/254 (13 March 2013); TBT Committee, Notification Addendum - Mexico WTO Doc G/TBT/N/MEX/254/Add.1 (6 March 2015); TBT Committee, Notification Addendum - Mexico WTO Doc G/TBT/N/MEX/254/Add.2 (27 March 2015). For more information about the final form of the label, see International Alliance for Responsible Drinking, Health Warning Labeling Requirements, above n 12.

${ }^{79}$ TBT Committee, Notification - Turkey, WTO Doc G/TBT/N/TUR/41 (6 August 2013).

${ }^{80}$ TBT Committee, Notification - South Africa, WTO Doc G/TBT/N/ZAF/48/Rev.1 (3 December 2014). For further detail of the proposal, see United States Department of Agriculture, Foreign Agricultural Service 'Republic 
warnings include: 'alcohol reduces driving ability, don't drink and drive'; 'don't drink and walk on the road, you may be killed'; 'alcohol increases your risk [of] personal injuries'; 'alcohol is a major cause of violence and crime'; 'alcohol abuse is dangerous to your health'; 'alcohol is addictive' and 'drinking during pregnancy can be harmful to your unborn baby'. ${ }^{81}$ The changes appear not to be in effect yet.

In 2015 and 2016, new labelling proposals subject to discussion in the TBT Committee included India's warning, 'alcohol is injurious to your health', ${ }^{82}$ and Ireland's requirement to warn about harms to health and pregnancy from alcohol consumption (with the relevant Minister apparently having the power to set the content and design of the warnings). ${ }^{83}$ Neither appears to have come into effect yet. Korea amended its labelling laws to include a strong statement about the dangers of drinking during pregnancy, which identified the risk of 'congenital anomaly'. ${ }^{84}$ Korea appears now to have three alcohol warning statements, with manufacturers being able to choose one of these to apply to their products. The statements warn about matters such as alcohol being a carcinogen, and excessive drinking causing cancer, gastric adenocarcinoma, stroke, memory loss and dementia. ${ }^{85}$

\section{$2 \quad$ Other Information Requirements and Restrictions}

Beyond health warnings, WTO members proposed alcohol labelling rules to require a range of further information (including some health information). They also placed limits on the information that manufacturers can place on the alcohol label. Two members of the East African Community, ${ }^{86}$ Kenya $^{87}$ and Uganda, ${ }^{88}$ proposed identical standards to apply to a

of South Africa: Regulation Amendment on Container Labels of Alcoholic Beverages' (Report, Global Agricultural Information Network, 30 January 2015).

${ }^{81}$ Regulations Relating to Health Messages on Container Labels of Alcoholic Beverages (South Africa) reg 764 (24 August 2007) Annexure A.

${ }^{82}$ TBT Committee, Notification - India, WTO Doc G/TBT/N/IND/51 (1 December 2015). See also: ANA Law Group, Indian Language Labelling Requirements on Packaged Goods (30 September 2016) $<\mathrm{http}: /$ www.anaassociates.com/indian-language-labelling-requirements-on-packaged-goods/>. It appears that some states in India may already require warning messages on alcoholic beverages sold within their jurisdiction only: see Robin Room et al, Alcohol and Developing Societies: A Public Health Approach (2002) (Finnish Foundation for Alcohol Studies, Helsinki \& World Health Organization, Geneva) 57.

${ }^{83}$ TBT Committee, Notification - Ireland, WTO Doc G/TBT/N/IRL/2 (7 June 2016). See Public Health (Alcohol) Bill 2015 [Law No 120 of 2015] (Ireland).

${ }^{84}$ TBT Committee, Notification - Korea, WTO Doc G/TBT/N/KOR/664 (29 July 2016). This notification is by the Republic of Korea (South Korea). The Democratic People's Republic of Korea (North Korea) is not a member of the WTO.

${ }^{85}$ International Alliance for Responsible Drinking, Health Warning Labeling Requirements, above n 12.

${ }^{86}$ The East Africa Community is a customs union consisting of the Republics of Burundi, Kenya, Rwanda, South Sudan, the United Republic of Tanzania, and the Republic of Uganda. The East Africa Community is not a WTO member. See East Africa Community, Overview of East Africa Community (2017) $<$ http://www.eac.int/about/overview>.

${ }^{87}$ See TBT Committee, Notification - Kenya, WTO Doc G/TBT/N/KEN/483 (6 July 2016); TBT Committee, Notification - Kenya, WTO Doc G/TBT/N/KEN/482 (6 July 2016); WTO Doc G/TBT/N/KEN/479 (6 July 2016); WTO Doc G/TBT/N/KEN/477 (5 July 2016); WTO Doc G/TBT/N/KEN/476 (5 July 2016); WTO Doc G/TBT/N/KEN/475 (5 July 2016); WTO Doc G/TBT/N/KEN/474 (5 July 2016); WTO Doc G/TBT/N/KEN/473 (5 July 2016); WTO Doc G/TBT/N/KEN/472 (5 July 2016).

${ }^{88}$ See TBT Committee, Notification - Uganda, WTO Doc G/TBT/N/UGA/441 (8 January 2015); WTO Doc G/TBT/N/UGA/440 (8 January 2015); WTO Doc G/TBT/N/UGA/439 (8 January 2015); WTO Doc G/TBT/N/UGA/438 (8 January 2015); WTO Doc G/TBT/N/UGA/437 (8 January 2015); WTO Doc G/TBT/N/UGA/436 (8 January 2015); WTO Doc G/TBT/N/UGA/435 (8 January 2015); WTO Doc G/TBT/N/UGA/434 (8 January 2015). There were separate notifications for each variety of alcoholic beverage, with the proposed standards relating not only to labelling, but also to the compositional requirements and 
variety of alcoholic beverages, with requirements for labelling of the products with ingredients lists, alcohol content, best before dates, the name of the manufacturer, and the country of origin. Ecuador required the name of the importer of alcoholic beverages to be placed on the container's front label at the time of manufacture. ${ }^{89}$ In addition to its specific health warning for alcoholic beverages (see above), India also required nutrition labelling, best before dates (for wine and spirits), and ingredients lists (with some exemptions) as part of a general food labelling measure that encompassed alcohol. ${ }^{90}$ Mexico also mandated the provision of information about the geographic origin of the product. ${ }^{91}$ Brazil imposed a range of labelling requirements including that the alcohol content be noted on the front label and a registration sign be applied to all products, as well as the translation into Portuguese of label contents. ${ }^{92}$ This same proposal by Brazil included restrictions on certain images and words being used on the label..$^{93}$ Then, in a later separate measure, Brazil set quality and composition standards for certain alcoholic beverages, with related restrictions on the use of names to describe such products. ${ }^{94}$ Turkey also required that signs, brands and trademarks from alcoholic beverages not be used on non-alcoholic beverages (and vice versa). ${ }^{95}$ Thailand also adopted a highly contentious set of restrictions in 2015, which prohibit certain messages being used on the labels of alcoholic beverages, including images of artists, athletes, or singers, or cartoons. ${ }^{96}$

\section{WTO Member Concerns About Alcohol Labelling Proposals}

In this Part, we draw out from the minutes of the TBT Committee meetings the aspects of the labelling policies, discussed in Part III.B, that have been subject to the most extensive consultation between the members. These are the aspects of policies that have been discussed in multiple meetings, have drawn comments from several major alcohol exporting countries, have had extensive concerns raised about them repeatedly, and have had objections expressed in strong language. Although the industry may prefer that government does not regulate alcoholic beverages at all, the analysis here suggests that where government does intervene to mandate labelling, it is specific aspects of such labelling schemes that are a problem for the alcohol industry. It seems therefore that it is not health labelling per se that is resisted by the alcohol industry. Its objections turn on: (1) the content of the warning messages; (2) graphic imagery forming part of the warning messages; (3) design requirements being mandated for the labels; (4) rotation requirements being mandated for the labels; (5) government's refusal to allow stickers or supplementary labelling; and (6) restrictions on the industry marketing images and messages on the label space.

\footnotetext{
allowances for each variety of beverage. The standard for the composition of whisky is likely to prove contentious: see Committee on Technical Barriers to Trade, Minutes, WTO Doc G/TBT/M/70, above n 72, [2.34] (EU).

${ }^{89}$ TBT Committee, Notification - Ecuador, WTO Doc G/TBT/N/ECU/243 (28 April 2014).

${ }^{90}$ TBT Committee, Notification — India, WTO Doc G/TBT/N/IND/46 (24 October 2013).

${ }^{91}$ TBT Committee, Notification - Mexico, WTO Doc G/TBT/N/254 (13 March 2013); TBT Committee, Notification - Addendum - Mexico WTO Doc G/TBT/N/254/Add.1 (6 March 2015); TBT Committee, Notification - Addendum - Mexico WTO Doc G/TBT/N/254/Add.2 (27 March 2015).

92 TBT Committee, Notification - Brazil, WTO Doc G/TBT/N/BRA/348 (29 September 2009) and G/TBT/N/BRA/348 /Suppl.1 (9 November 2009).

${ }^{93}$ Ibid.

94 TBT Committee, Notification — Brazil, WTO Doc G/TBT/N/BRA/613 (5 December 2014).

${ }^{95}$ TBT Committee, Notification - Turkey, WTO Doc G/TBT/N/TUR/41 (6 August 2013). Presumably, this might cover a situation where Coca-Cola Amatil is the distributor of an alcoholic beverage in Turkey and has been applying its brand and trademark to those alcoholic beverages, as well as to its non-alcoholic soft drink lines.

96 TBT Committee, Notification - Thailand, WTO Doc G/TBT/N/THA/437 (28 March 2014); WTO Doc G/TBT/N/THA/437/Add.1 (29 April 2015).
} 
In our analysis of each of these contentious labelling issues, we also identify the trade law arguments that have been raised by members about these proposals. The arguments are principally and understandably those arising under the TBT Agreement, as it is that Agreement that establishes and empowers the Committee where these matters are being ventilated. In some instances, members have also indicated trade concerns arising under other WTO agreements. Members often ask questions or seek information which would be relevant to claims under the TBT Agreement, should dispute settlement proceedings be initiated in relation to a notified measure. Some of the arguments made against labelling proposals reflect the interpretations of the TBT Agreement by WTO panels and the Appellate Body. ${ }^{97}$ In summary, the most common argument rests on article 2.2 of the TBT Agreement: that the measure or some aspect of it is unnecessarily trade restrictive. ${ }^{98}$ Members also turn frequently to article 2.4 , asserting that the measure is not consistent with a relevant international standard. ${ }^{99}$ Claims of discrimination in the form of less favourable treatment of imported products compared to domestic products, under article 2.1, have been relatively rare in relation to alcohol labelling. ${ }^{100}$

The content of the warning message has been shown to be critical to the acceptability of the label to other WTO members. Warnings that suggest that drinking per se is a problem are very vehemently opposed as being more trade restrictive than necessary to achieve the measure's (usually conceded) legitimate objective. For example, Thailand's labels stated 'drinking alcohol causes liver cirrhosis' (italics added). Many states opposed these labels on the basis that it is only the 'dangerous' or 'excessive consumption' of alcohol that is problematic, ${ }^{101}$ and that 'moderate' consumption is, in fact, good for your health. ${ }^{102}$ Mexico claimed in relation to Thailand that giving warnings against any alcohol consumption is ignoring the science about the health benefits of alcohol consumption. ${ }^{103}$ Similarly, India's warning that 'consumption of

\footnotetext{
${ }^{97}$ See eg, Appellate Body Reports, US - COOL [Country of Origin Labelling] - Recourse to Article 21.5 of the DSU by Canada and Mexico, WTO Doc WT/DS384/AB/RW, WT/DS386/AB/RW (18 May 2015); Appellate Body Reports, European Communities - Measures Prohibiting the Importation and Marketing of Seal Products, WTO Doc WT/DS400/AB/R, WT/DS401/AB/R (22 May 2014) ('EC — SEAL'); Appellate Body Reports, United States - Certain Country of Origin Labelling (COOL) Requirements, WTO Doc WT/DS384/AB/R, WT/DS386/AB/R (29 June 2012); Appellate Body Report, United States - Measures Concerning the Importation, Marketing and Sale of Tuna and Tuna Products, WTO Doc WT/DS381/AB/R (16 May 2012) ('US - Tuna II (Mexico)'); Appellate Body Report, United States - Measures Affecting the Production and Sale of Clove Cigarettes, WTO Doc WT/DS406/AB/R (4 April 2012) [96]-[102]; Panel Report, United States Measures Affecting the Production and Sale of Clove Cigarettes, WTO Doc WT/DS406/R (2 September 2011); Appellate Body Report, Brazil - Measures Affecting Imports of Retreaded Tyres, WTO Doc WT/DS332/AB/R (3 December 2007) ('Brazil - Retreaded Tyres'); Appellate Body Reports, Korea - Measures Affecting Imports of Fresh, Chilled and Frozen Beef, WTO Doc WT/DS161/AB/R, WT/DS169/AB/R (11 December 2000).

98 TBT Agreement, above n 18, art 2.2.

${ }^{99}$ Ibid art 2.5.

${ }^{100}$ Ibid art 2.1. See also Tania Voon, Andrew Mitchell and Catherine Gascoigne, 'Consumer Information, Consumer Preferences and Product Labels under the TBT Agreement' in Tracey Epps and Michael J Trebilcock (eds), Research Handbook on the WTO and Technical Barriers to Trade (Edward Elgar, 2013) 454, 461.

${ }^{101}$ TBT Committee, Minutes of the Meeting of 3-4 November 2010, WTO Doc G/TBT/M/52 (10 March 2011) [240]-[241] (Chile); TBT Committee, Minutes of the Meeting Held of 24-25 March 2010, WTO Doc G/TBT/M/50 (28 May 2010) [4] (Mexico); TBT Committee, Minutes of the Meeting of 23-24 June 2010, WTO Doc G/TBT/M/51 [243] (Chile), [237] (EU).

${ }^{102}$ See, eg, TBT Committee, Minutes, WTO Doc G/TBT/M/52, above n 104 [241] (Chile); see also TBT Committee, Minutes, WTO Doc G/TBT/M/70, above n 72 [2.25] (Mexico).

${ }^{103}$ See TBT Committee, Minutes, WTO Doc G/TBT/M/50, above n 104 [4] (Mexico); TBT Committee, Minutes, WTO Doc G/TBT/M/51, above n 104 [239] (Mexico).
} 
alcohol is injurious to health' has been recommended for revision to 'consumption of alcohol can be injurious to health' (italics added). ${ }^{104}$

The harms that are linked to alcohol consumption are also subject to considerable discussion in the TBT Committee. It seems that members are generally not opposed to warnings that advise against drinking and driving, and drinking while pregnant, and that warnings about these harms can be tolerated. The substantive content of the Irish message about the harms arising from drinking during pregnancy only drew comment from Mexico in the TBT Committee. ${ }^{105}$ Yet, members repeatedly called for Thailand to provide the scientific evidence to justify the content of its warnings, which, as noted above, referred to the links between alcohol and cirrhosis, suicide, sexual function, and family violence. ${ }^{106}$ The only Thai warning that the US expressly indicated that it did not seek a justification for was that relating to drinking and driving. ${ }^{107}$

Korea's warnings about the links between cancer and alcohol consumption have also been attacked in the TBT Committee. One of Korea's warnings states, 'Alcohol is [a] carcinogen, so excessive drinking causes cancer of the liver and stomach...'. Mexico contested this warning, on the basis that it did not provide clear information to the consumer, saying there is 'no scientific evidence establishing such a causal link, since epidemiological studies pointed to a wide range of cancer risk factors, including family history, genetics, lifestyle and environmental factors'. ${ }^{108}$ Therefore, the message was argued to be unnecessarily burdensome for international trade, particularly given that 'moderate consumption of alcohol was also regarded as an important part of a healthy lifestyle' in scientific studies. ${ }^{109}$ Australia added to Mexico's comments, calling for Korea to provide a translation of the warning, because some translations of the warnings suggested a 'direct link' between cancer and drinking. Australia 'suggested that the label be drafted in a way that would reflect scientific consensus on the issue'. ${ }^{110}$ The EU's objection was that the warning should mention that it was higher levels of consumptions and harmful consumption patterns that made it more likely that harm would occur. ${ }^{111}$ With Korea's warnings, it is arguably both the specific mention of serious and lifethreatening diseases (as opposed to a general warning about 'health') and the claim of a causal connection that unsettles some members. Also, the mentions of other cancers, besides liver cancer, seem to be unacceptable.

Finally, the issues of trade restrictiveness and also discrimination have arisen in relation to the approach adopted by Mexico and Israel to have different warnings for alcoholic beverages of different strengths. Of note was the fact that Mexico set 6 per cent alc/vol as the dividing line for the higher and lower warning levels, whereas Israel set it at 15.5 per cent alc/vol. The EU was particularly resistant to the two levels of warnings, insisting that it is excessive alcohol

\footnotetext{
${ }^{104}$ TBT Committee, Minutes of the Meeting of 29-30 March 2017, WTO Doc G/TBT/M/71 (2 June 2017) [2.192] (Canada).

${ }^{105}$ See ibid [2.777] (Mexico); TBT Committee, Minutes, WTO Doc G/TBT/M/70, above n 72 [2.13]-[2.14] (Mexico); TBT Committee, Minutes of the Meeting of 14-15 June 2017, WTO Doc G/TBT/M/72 [3.220] (Mexico). The issue here seems to be less about the content of the message and more about Ireland setting different labelling requirements from other members of the EU.

${ }^{106}$ TBT Committee, Minutes, WTO Doc G/TBT/M/51, above n 104 [237] (EU); TBT Committee, Minutes, WTO Doc G/TBT/M/50 above n 104 [6] (Argentina), [7] (NZ), [11] (US).

107 TBT Committee, Minutes, WTO Doc G/TBT/M/50, above n 104 [11] (US).

${ }^{108}$ TBT Committee, Minutes, WTO Doc G/TBT/M/70, above n 72 [2.25] (Mexico).

${ }^{109}$ Ibid [2.25] (Mexico).

${ }^{110}$ Ibid [2.29] (Australia).

111 TBT Committee, Minutes, WTO Doc G/TBT/M/71, above n 107 [2.261] (EU).
} 
consumption alone that causes harm and there is no basis for distinguishing between 'strong intoxicating beverages and regular intoxicating beverages'. ${ }^{112}$ The EU raised the issue of consumers being misled by the bifurcated messaging.

The inclusion of pictorial warnings, in addition to text, seemed to be an additional basis for concern about the Thai labels, ${ }^{113}$ with members claiming that the measure was more restrictive of trade than was necessary to achieve Thailand's legitimate objective of addressing harms from alcohol, having no basis in science. The images proposed by Thailand were explicit and potentially distressing, including photograph-style pictures of the dangling feet of a person who had, by implication, hanged him- or herself, a mother cradling a child who had been knocked off a bike by an intoxicated driver, and a man beating a cowering person whilst a child pulls at the attacker's leg. ${ }^{114}$ Since the Thai labelling proposal, no notification that has come before the TBT Committee has concerned the use of such graphic labels, although members, particularly the US, seemed concerned that Kenya's proposal might include pictures. ${ }^{115}$ The Turkish proposal did include pictograms and was criticised by members, ${ }^{116}$ but, as discussed above, the industry itself now supports the use of pictograms for advice about the specific risks covered by the Turkish labels - drink driving and drinking during pregnancy. It seems therefore that it is the use of realistic images on labels, and not the use of pictograms, ${ }^{117}$ that is an issue for the industry.

Where members propose labelling regimes with strict design requirements, there appears to be resistance by other members to the proposals. In the TBT Committee, the concerns have been expressed both in terms of the measure being unnecessarily trade restrictive, as well as an interference with brands and marks. A major sticking point between members has been labelling rules that not only require that the label warning be 'legible' but prescribe that the warning take up a large proportion of the surface area of the beverage container. In relation to Thailand, the proposal was for the warning to be 30-50 per cent of the package surface area; in Kenya, it was 30 per cent.

The US was strongly opposed to both members' rules, raising the argument that the warning would take up so much space it would not leave enough room for trademarks and other

\footnotetext{
${ }^{112}$ TBT Committee, Minutes of the Meeting of 30-31 October 2013, WTO Doc G/TBT/M/61 [2.106] (EU). See also TBT Committee, Minutes of the Meeting of 5-6 November 2014, WTO Doc G/TBT/M/64 (10 February 2015) [2.44]; TBT Committee, Minutes of the Meeting of 17, 19 and 20 June 2013, WTO Doc G/TBT/M/60 (23 September 2013) [3.134] (EU); TBT Committee, Minutes of the Meeting of 6-7 March 2013, WTO Doc G/TBT/M/59 (8 May 2013) [2.179] (EU).

${ }^{113}$ See, eg, TBT Committee, Minutes, WTO Doc G/TBT/M/50 above n 104 [4] (Mexico), [5] (EU), [11] (US).

${ }^{114}$ See European Alcohol Policy Alliance, above n 73.

${ }^{115}$ TBT Committee, Minutes of the Meeting of 15-16 June 2011, WTO Doc G/TBT/M/54 (20 September 2011) [92] (US); TBT Committee, Minutes of the Meeting of 10-11 November 2011, WTO Doc G/TBT/M/55 (9 February 2012) [247] (US); TBT Committee, Minutes of the Meeting of 20-21 March 2012, WTO Doc G/TBT/M/56 (16 May 2012) [207] (US).

${ }^{116}$ See, eg, TBT Committee, Minutes, WTO Doc G/TBT/M/61, above n 115 [2.36] (Canada), [2.37] (Mexico), [2.38] (EU).

${ }^{117}$ See, eg, Lisa Thomson, Brian Vandenberg and John Fitzgerald, 'An Exploratory Study of Drinkers' Views of Health Information and Warning Labels on Alcohol Containers' (2012) 31 Drug and Alcohol Review 240, 242.
} 
information required to distinguish one producer's product from others. ${ }^{118}$ The US also expressed concern that the large label size meant that marks would be covered and products would be more susceptible to counterfeiting. ${ }^{119}$ The US specifically called for Thailand to share the science that supported the sizing rule. ${ }^{120}$ The EU also expressed considerable concern about the label sizing requirements. ${ }^{121}$ Mexico argued that it was, in fact, not necessary to set a minimum size in order to achieve the legitimate objective of reducing alcohol-related harm. ${ }^{122}$ Similarly, Chile said that any warning should be less than 15 per cent of the label (not container) space. ${ }^{123}$

A further issue arises where there is a requirement that the mandated warning information appear on the front label, with no flexibility for manufacturers as to where to place the label. This was contentious in the Thai labelling proposal as being more trade restrictive than necessary. ${ }^{124}$ It was also a matter raised in the TBT Committee about the Ecuadorian proposal. ${ }^{125}$ Canada noted in its comments to Ecuador that its proposal to require front of container information conflicted with international practice that allowed for producers to apply generic front labels (in their country of origin) and apply country-specific information to the back label (once the product was imported). ${ }^{126}$ The EU claimed that the front of container requirement in the Israeli proposal would have a 'burdensome and costly impact on imports'. ${ }^{127}$ Israel later informed the Committee that it had dropped this requirement. ${ }^{128}$

Concerns about the imposition of other formatting requirements, such as the size and style of the font, and the layout and design of the label, have also been raised in the TBT Committee. The Turkish proposal was highly prescriptive about these features, which led the EU to call the labelling content, formatting and placement requirements 'excessive'. ${ }^{129}$ It appears that Turkey later decreased the size of the warning on some packages. ${ }^{130}$

\section{Rotation of Warning Labels}

The requirement to rotate warning labels is raised as a particular burden on international trade. Thailand had proposed that labels be rotated every 1,000 units. The US described this as

\footnotetext{
${ }^{118}$ TBT Committee, Minutes of the Meeting of 13-15 June 2012, WTO Doc G/TBT/M/57 (18 September 2012) [88] (US); TBT Committee, Minutes, WTO Doc G/TBT/M/55, above n 118 [247] (US); TBT Committee, Minutes, WTO Doc G/TBT/M/54, above n 118 [92] (US); TBT Committee, Minutes, WTO Doc G/TBT/M/52, above n 104 [237] (US); TBT Committee, Minutes, WTO Doc G/TBT/M/51, above n 104 [240] (US).

${ }^{119}$ TBT Committee, Minutes, WTO Doc G/TBT/M/56, above n 118 [77] (US).

${ }^{120}$ TBT Committee, Minutes of the Meeting of 24-25 March 2011, WTO Doc G/TBT/M/53 (26 May 2011) [229] (US).

${ }^{121}$ TBT Committee, Minutes, WTO Doc G/TBT/M/56, above n 118 [208] (EU); TBT Committee, Minutes, WTO Doc G/TBT/M/55, above n 118 [248] (EU); TBT Committee, Minutes, WTO Doc G/TBT/M/54, above n 118 [89] (Mexico).

${ }^{122}$ TBT Committee, Minutes, WTO Doc G/TBT/M/50, above n 104 [4] (Mexico).

${ }^{123}$ TBT Committee, Minutes, WTO Doc G/TBT/M/51, above n 104 [243] (Chile).

${ }^{124}$ TBT Committee, Minutes, WTO Doc G/TBT/M/50, above n 104 [5] (EU).

${ }^{125}$ TBT Committee, Minutes of the Meeting of 18-19 March 2015, WTO Doc G/TBT/M/65 (28 May 2015)

[2.194] (Canada); TBT Committee, Minutes of the Meeting of 17-18 June 2015, WTO Doc G/TBT/M/66 (17 September 2015) [3.181] (US).

${ }^{126}$ TBT Committee, Minutes, WTO Doc G/TBT/M/65, above n 129 [2.194].

${ }^{127}$ TBT Committee, Minutes, WTO Doc G/TBT/M/60, above n 115 [3.134] (EU).

${ }^{128}$ TBT Committee, Minutes, WTO Doc G/TBT/M/61, above n 115 [2.108] (Israel).

${ }^{129}$ Ibid [2.38] (EU).

${ }^{130}$ TBT Committee, Notification - Turkey, WTO Doc G/TBT/N/TUR/41/Add.2 (25 March 2014).
} 
'onerous', ${ }^{131}$ and Australia shared the US's concerns. ${ }^{132}$ The US claimed that the requirement would necessitate 'a stop and change in the production every three to four minutes, which would be extremely difficult for suppliers to manage and very disruptive to the production process', ${ }^{133}$ and it asked Thailand to provide the science behind the rotation requirement. ${ }^{134}$ Kenya's requirement that labels be swapped every 50 packages was even more demanding than the Thai proposal and met resistance from Mexico, ${ }^{135}$ and again from the US. ${ }^{136}$ It is notable that South Africa has had warning labels in place since 2007, with manufacturers able to choose from a set of labels. However, South Africa has proposed the rotation of labels so that each of the seven prescribed labels occur in equal regularity in a 12-month period. This means that producers are no longer able to choose their preferred warning. Both the EU and Canada have raised concerns that the new rule would be a major burden on small and medium producers who are not sending large amounts of product to South Africa. ${ }^{137}$ The EU also asked how the rule would work for products with a long shelf life. ${ }^{138}$

\section{Refusal to Use Stickers or Supplementary Labels}

The resistance of members to the use of stickers for the presentation of country-specific government mandated information has been a source of tension in the TBT Committee between, on the one hand, the EU and US, and on the other hand a number of notifying members. ${ }^{139}$ The issue has arisen in relation to several labelling proposals, but has been a persistent theme of members' interactions with India in the TBT Committee since 2014. In relation to both labelling proposals by India (for ingredients lists, nutritional and best before information etc and for warnings), India initially refused members' requests to allow stickering. The EU and others insisted that there is a relevant international standard as to stickering to which India should be adhering, ${ }^{140}$ thereby implying that India's position is inconsistent with the requirement in article 2.4 that members use relevant international standards unless they are ineffective or inappropriate. The EU claimed that 'stickering' is provided for in the Codex General Standard for the Labelling of Pre-packaged Food ('Codex Standard 1-1985'), ${ }^{141}$ which states that, 'if the language on the original label is not acceptable to the consumer for whom it is intended, a supplementary label containing the mandatory information in the required language may be used instead of re-labelling ${ }^{142}$ and 'in the case of either re-labelling

\footnotetext{
131 TBT Committee, Minutes, WTO Doc G/TBT/M/52, above n 104 [237] (US). See also TBT Committee, Minutes, WTO Doc G/TBT/M/51, above n 104 [241] (US); TBT Committee, Minutes, WTO Doc G/TBT/M/50, above n 104 [11] (US).

${ }^{132}$ TBT Committee, Minutes, WTO Doc G/TBT/M/51, above n 104 [242] (Australia).

${ }^{133}$ Ibid [241] (US).

${ }^{134}$ TBT Committee, Minutes, WTO Doc G/TBT/M/53, above n 124 [227] (US).

135 TBT Committee, Minutes, WTO Doc G/TBT/M/54, above n 118 [90] (Mexico).

${ }^{136}$ Ibid [92] (US); TBT Committee, Minutes, WTO Doc G/TBT/M/55, above n 118 [247] (US).

${ }^{137}$ TBT Committee, Minutes of the Meeting 9-10 March 2016, WTO Doc G/TBT/M/68 (12 May 2016) [2.21] (EU) [2.22] (Canada).

${ }^{138}$ Ibid [2.21] (EU).

${ }^{139}$ There has been some attempt by some members to address this issue through the inclusion of a provision in new bilateral and regional trade and investment agreements which expressly obliges states parties to allow supplementary labelling of wine and spirits: see O'Brien et al, 'Marginalising Health Information', above n 19.

${ }^{140}$ TBT Committee, Minutes of the Meeting of 5-6 November 2014, WTO Doc G/TBT/M/64/Rev.1 (6 March 2015) [2.118] (EU).

${ }^{141}$ TBT Committee, Minutes, WTO Doc G/TBT/M/66, above n 129 [3.96]; TBT Committee, Minutes, WTO Doc G/TBT/M/64/Rev.1, above n 144 [2.120] (Switzerland).

${ }^{142}$ Codex Alimentarius Commission, General Standard for the Labelling of Prepackaged Foods (Codex Standard 1-1985, adopted $14^{\text {th }}$ session 1981, as revised $19^{\text {th }}$ session, 1991) $\mathrm{cl} 8.2 .1$ $<$ http://www.fao.org/docrep/005/Y2770E/y2770e02.htm>.
} 
or a supplementary label, the mandatory information provided shall fully and accurately reflect that in the original label'. ${ }^{143}$ The EU argued that the provision of the required information by way of stickers (applied at a customs bonded warehouse in India) were also 'a sound alternative to labelling in the country of origin that would allow India to fulfil its legitimate objectives in a non-trade restrictive way'. ${ }^{144}$ Other members shared the EU's concerns. ${ }^{145}$ Switzerland claimed that firms were 'pulling out of the Indian market due to these restrictive measures [of not allowing stickering]'. ${ }^{146}$ Japan was concerned that '[the Codex's] well-balanced standard reflected real world practices whereby many countries, including Japan, allowed food products to be labelled by means of stickers provided they were accurate and not easily detachable, achieving consumer protection while, at the same time, avoiding unnecessary trade disruption'. ${ }^{147}$

Initially, India was firm in its refusal to allow any stickering: it said it was concerned about their 'misus[e] by unscrupulous traders for manipulating or tampering with the labels...' ${ }^{148}$ It insisted that stickering would compromise the 'sanctity of information' that is essential to consumer choice. ${ }^{149}$ It further argued that there is no international standard governing the labelling of alcoholic beverages. ${ }^{150}$ However, it has agreed more recently to allow stickering for some label information (eg, importer details), but not warnings, ingredients lists and nutrition labelling. ${ }^{151}$

\section{$6 \quad$ Restrictions on Producer Label Content}

A final issue of major concern to members has been the policy of prohibiting producers from using certain content on their product labels. This issue has arisen in two recent instances. Brazil's labelling prohibition flows from its setting of standards for the composition of alcoholic beverages and includes restrictions on the use of terms such as 'dry' or 'reserve', as well as the 'evocations of certain names protected in the EU'. ${ }^{152}$ The new Thai rule prohibits the use of words and images that would mislead the consumer, encourage consumption or lead to 'negative social consequences', and, as noted above, specifically prohibits pictures of athletes, singers, artists and cartoons. Labels must also be approved by an administrative agency. A key concern by certain WTO members has been the lack of clarity about the rules and important definitions, and the consequent possibility of differing interpretations by different 'economic operators' ${ }^{153}$ and unwitting infringement. ${ }^{154}$ The US has complained repeatedly about the "vague language and the excessive enforcement discretion it conferred on individual officers'. ${ }^{155}$ New Zealand described the rules as 'unworkable' for this reason. ${ }^{156}$

\footnotetext{
${ }^{143}$ Ibid cl 8.2.2.

${ }^{144}$ TBT Committee, Minutes, WTO Doc G/TBT/M/64/Rev.1, above n 144 [2.118] (EU).

${ }^{145}$ See, eg, TBT Committee, Minutes, WTO Doc G/TBT/M/68, above n 141 [2.22] (Canada), 2.24 (South Africa).

${ }^{146}$ TBT Committee, Minutes, WTO Doc G/TBT/M/64/Rev.1, above n 144 [2.120] (Switzerland).

${ }^{147}$ Ibid [2.121] (Japan).

${ }^{148}$ Ibid [2.124] (India).

149 TBT Committee, Minutes, WTO Doc G/TBT/M/66, above n 129 [3.101] (India).

${ }^{150}$ TBT Committee, Minutes, WTO Doc G/TBT/M/70, above n 72 [2.249] (India).

${ }^{151}$ See TBT Committee, Minutes, WTO Doc G/TBT/M/71, above n 107 [2.198].

152 TBT Committee, Minutes, WTO Doc G/TBT/M/66, above n 129 [3.37] (EU).

${ }^{153}$ TBT Committee, Minutes, WTO Doc G/TBT/M/70, above n 72 [2.150] (EU).

${ }^{154}$ TBT Committee, Minutes of the Meeting 18-19 June 2014, WTO Doc G/TBT/M/63 (19 September 2014) [3.9]-[3.11].

155 TBT Committee, Minutes, WTO Doc G/TBT/M/71, above n 107 [2.137] (US).

${ }^{156}$ TBT Committee, Minutes, WTO Doc G/TBT/M/70, above n 72 [2.153] (NZ).
} 
The Thai labels are argued to be more trade restrictive than necessary, with members, including the US, asking for the scientific and technical information to justify the rules. ${ }^{157}$ Other members have put onto the record that their producers' use of cartoons and the like are not intended to appeal to children, thereby suggesting that there is no harm flowing from the use of such images to be ameliorated by the measure and that the measure is unjustified. ${ }^{158}$ Mexico went so far as to submit a statement to the TBT Committee of its concerns about the rules. Along with other members, Mexico highlighted that the measure may be more restrictive than necessary to achieve Thailand's legitimate objectives, and may also infringe the intellectual property rights of producers and the TRIPS Agreement. ${ }^{159}$

The new Thai rule restricting marketing on alcoholic beverage labels has come into effect. Thailand claims that the rule does not infringe any intellectual property rights and does not obstruct international trade, ${ }^{160}$ and that the measure is consistent with measures in other countries.

\section{AlCOHOL LABELLING AND THE TBT AGREEMENT}

The preceding Part outlined WTO members' extensive concerns with: (1) the content of warning messages; (2) the use of emotive and realistic imagery as part of warning messages; (3) mandatory design and placement requirements that would result in the warning assuming a prominent appearance and position on the container; (4) the insistence on rotation of warnings to prevent consumer de-sensitisation; (5) the prohibition of health information being placed on stickers or supplementary labels; and (6) restrictions on the industry's choice of words and images for the beverage label. The review of the TBT Committee meeting minutes suggests that it is not alcohol labelling per se that raises concerns for WTO members, but that specific aspects of government labelling proposals are problematic. In this part, we highlight some of the critical legal and evidentiary issues that are raised by the main trade law arguments being used in the TBT Committee meetings against alcohol health labelling. In Part IV.B, we focus on article 2.2 of the TBT Agreement, considering this provision in relation to the contested aspects of alcohol health warnings. Article 2.2 prohibits unnecessarily trade restrictive measures and is the main provision invoked by WTO members in the TBT Committee meeting discussions about alcohol health labelling. In Part IV.C, we also consider article 2.4 of the Agreement in relation to other health information requirements, such as ingredients lists and nutrition labelling. Article 2.4 requires that a measure such as a labelling requirement be based on relevant international standards unless they would be ineffective or inappropriate to achieve the measure's objectives. Rather than comprehensively analysing how articles 2.2 and 2.4 would apply to each of the labelling proposals discussed above in Part III.A, we outline the main features of these important provisions of the TBT Agreement and identify some of the likely points of dispute between members in relation to warnings and other health information. In doing so, we specifically reflect on the ways in which the legal arguments connect to the global public health policy debates about alcohol control. First, we will explain briefly the scope of the TBT Agreement and confirm its coverage of alcohol labelling measures.

\footnotetext{
${ }^{157}$ Ibid [2.148] (US).

${ }^{158}$ Ibid [2.149] (Canada), [2.155] (Guatemala).

${ }^{159}$ TBT Committee, Thailand - Draft Notification of the Alcoholic Beverages Control Re: Rules, Procedures and Conditions for Labels of Alcoholic Beverages: Statement by Mexico to the Technical Barriers to Trade Committee at its Meeting of 18-19 March 2015, WTO Doc G/TBT/W/408 (8 May 2015); TBT Committee, Minutes, WTO Doc G/TBT/M/63, above n 158 [3.11].

${ }^{160}$ TBT Committee, Minutes, WTO Doc G/TBT/M/70, above n 72 [2.156] (Thailand).
} 


\section{A The TBT Agreement and Technical Regulations}

The TBT Agreement applies to 'technical regulations', ${ }^{161}$ 'standards', ${ }^{162}$ and 'procedures for assessment of conformity'. ${ }^{163}$ A 'technical regulation', the most relevant concept for alcohol labelling, is defined as a '[d] ocument which lays down product characteristics ... with which compliance is mandatory. It may also include or deal exclusively with terminology, symbols, packaging, marking or labelling requirements as they apply to a product ...' ${ }^{164}$ The Appellate Body has characterized the 'labelling' and other requirements listed in the second sentence as "examples of "product characteristics"" in the first sentence. ${ }^{165}$ It has held that a technical regulation must (i) apply to an identifiable group of products, and (ii) lay down one or more product characteristics, (iii) with which compliance is mandatory. ${ }^{166}$ Applying this definition, a rule by government mandating that packaged alcoholic beverages be labelled with health information or a health warning constitutes a 'technical regulation', because it specifies product characteristics in the form of labelling requirements, with which compliance is mandatory, for alcoholic beverages.

\section{B Health Warnings and Unnecessary Obstacles to International Trade: TBT Article 2.2}

Article 2.2 of the TBT Agreement is likely to be the main plank in a dispute about an alcohol labelling proposal. It is concerned with technical regulations by central government bodies and states:

Members shall ensure that technical regulations are not prepared, adopted or applied with a view to or with the effect of creating unnecessary obstacles to international trade. For this purpose, technical regulations shall not be more trade-restrictive than necessary to fulfil a legitimate objective, taking account of the risks non-fulfilment would create .... In assessing such risks, relevant elements of consideration are, inter alia: available scientific and technical information, related processing technology or intended end-uses of products.

The Appellate Body has made clear that article 2.2 does not simply prohibit measures that have any trade-restrictive effect. ${ }^{167}$ It only prohibits measures that limit international trade in a manner that 'exceed[s] what is necessary to achieve the degree of contribution that a technical regulation makes to the achievement of a legitimate objective'. ${ }^{168}$ The assessment of whether a technical regulation is more trade restrictive than necessary under article 2.2 involves a 'weighing and balancing, ${ }^{\text {, }}$ of the following factors: '(i) the degree of contribution made by the measure to the legitimate objective at issue; (ii) the trade-restrictiveness of the measure; and (iii) the nature of the risks at issue and the gravity of consequences that would arise from

\footnotetext{
${ }^{161}$ TBT Agreement, above n 18, Preamble [5].

162 Ibid.

163 Ibid.

${ }^{164}$ Ibid annex 1, [1] (emphasis added).

${ }^{165}$ Appellate Body Report, European Communities - Measures Affecting Asbestos and Asbestos-Containing Products, WTO Doc WT/DS135/AB/R (12 March 2001) [67] ('EC - Asbestos'). See also Appellate Body Report, European Communities - Trade Description of Sardines, WTO Doc WT/DS231/AB/R (26 September 2002) [189] ('EC-Sardines').

${ }^{166}$ Appellate Body Report, EC - Asbestos, above n 1659 [67]-[70]. See also Appellate Body Report, US - Tuna II (Mexico), above n 97 [183].

${ }^{167}$ Appellate Body Report, US — Tuna II (Mexico), above n 97 [319]; Appellate Body Reports, US - COOL, above n 97 [375]; Appellate Body Reports, US - COOL - Recourse to Article 21.5 of the DSU by Canada and Mexico, above n 97.

${ }^{168}$ Appellate Body Report, US - Tuna II (Mexico), above n 97 [319], quoted in Appellate Body Reports, US COOL, above n 97 [375].

${ }^{169}$ See, eg, Appellate Body Reports, US - COOL (Article 21.5 - Canada and Mexico), above n 167 [5.211].
} 
non-fulfilment of the objective(s) pursued by the Member through the measure'. ${ }^{170}$ Usually, 'a comparison with reasonably available alternative measures' will be undertaken 'as a conceptual tool' to determine 'whether a measure is more trade restrictive than necessary'. ${ }^{171}$ In the analysis below, we focus on the question of the degree of contribution made by a measure to its objective, as we consider this would be the most contentious issue in a WTO dispute about alcohol labelling, and it raises multiple intricate issues about the WTO jurisprudence and the public health evidence.

\section{$1 \quad$ Legitimate Objective}

A 'legitimate objective' includes 'protection of human health or safety'. ${ }^{172}$ The discussions in the TBT Committee suggest that members are generally supportive of other members' efforts to reduce harms from alcohol. If a member were to frame the objective of its labelling measure in this manner and to call evidence about the prevalence and nature of harms from alcohol consumption, and the rates and patterns of consumption (currently and longitudinally), ${ }^{173}$ most members would not dispute this as a legitimate objective to be pursued as a matter of domestic policy. For example, New Zealand, in its otherwise firm comments to Korea about its controversial new warnings, nonetheless recognised 'the harmful use of alcohol' as a legitimate public health concern. ${ }^{174}$

The framing of the objective also has the potential to affect the assessment of the extent of the contribution made by the measure to the fulfilment of the objective. ${ }^{175}$ For example, the US has accepted that a member may inform people about risks of excessive alcohol consumption. ${ }^{176}$ But this might be a more limited objective than addressing alcohol-related harms, and some measures, including labelling that creates fear or anxiety about health risks, might be seen as not well-suited to the mere provision of information).

The principal issue in a dispute about alcohol labelling under article 2.2 is likely to be the 'degree of contribution' made by the particular labelling measure to the public health objective. The Appellate Body has indicated that a measure is not required to meet a 'minimum threshold of fulfilment', ${ }^{177}$ but a measure must be shown as 'capable of making ... some contribution'178 to the legitimate objective of reducing alcohol-related harm. The degree of contribution (if any) made by a measure is ascertained by reference to the 'design, structure, and operation' of the measure, as well as the 'evidence relating to its application'. ${ }^{179}$ The debate about the evidence relevant to the question of contribution can be expected to be one of the most contentious aspects of a dispute. This conclusion is foreshadowed in the TBT Committee meeting minutes,

\footnotetext{
${ }^{170}$ Appellate Body Report, US - Tuna II (Mexico), above n 97 [322].

${ }^{171}$ Ibid [320]. See also Appellate Body Reports, US - COOL, above n 97 [376].

172 TBT Agreement, above n 18, art 2.2.

${ }^{173}$ Such evidence may be relevant to other aspects of the dispute about art 2.2, including the legitimacy of the member's objective in introducing alcohol health warning label, and the nature of the risk and gravity of the consequences if the objective were not fulfilled.

${ }^{174}$ TBT Committee, Minutes, WTO Doc G/TBT/M/70, above n 72 [2.28] (NZ).

175 Appellate Body Reports, US - COOL, above n 97 [382]-[433].

${ }^{176}$ TBT Committee, Minutes, WTO Doc G/TBT/M/70, above n 72 [2.27] (US).

${ }^{177}$ Appellate Body Reports, US - COOL, above n 97 [461].

${ }^{178}$ Appellate Body Reports, EC - SEAL, above n 97 [5.228], quoting Panel Reports, EC - SEAL WTO Doc WT/DS400/R, WT/DS401/R (25 November 2013) [7.460].

${ }^{179}$ Appellate Body Reports, US - COOL, above n 97 [373], citing Appellate Body Reports, US - Tuna II (Mexico), above n 97 [317].
} 
where members frequently call for the science underpinning particular features of labelling proposals, and proffer alternative opinions purportedly based in the science. ${ }^{180}$ We therefore turn to consider what science would be needed to assess a warning label's contribution to the objective of reducing harms from alcohol.

\section{(a) Evidence About the Effects of Warning Labels}

In terms of the type of evidence, the Appellate Body has made clear that quantitative evidence is not necessarily required, and that qualitative and other forms of scientific evidence may suffice. ${ }^{181}$ No evidence shows that health warning labels reduce harms from alcohol. Nevertheless, labels may contribute to reducing harms from alcohol through one of two mechanisms. Firstly, labels may lead an individual to change their drinking behaviour. Secondly, labels may, as discussed above, serve an expressive function in marking out alcohol as a risky product, thereby changing the cultural acceptability of alcohol and the drinking norms in the society. A member defending its measure is more likely to use the first mechanism to describe the way in which labels contribute to reducing harm, on the basis of existing evidence to support this claim. No studies to date would support reliance on the second mechanism, although it is arguable that this is the more potent effect of labels.

Assuming that labels can change drinking behaviour in the more direct manner envisaged in the first mechanism, do any studies show that labels reduce consumption (as the necessary precondition to harm)? As discussed above, the only natural experiment evidence available is that from the US, and it does not demonstrate reduced consumption. Rather, it shows changes in intervening variables, such as conversations about risks related to drinking, intentions to change drinking habits, or acting to deter another person from driving when intoxicated. ${ }^{182} \mathrm{~A}$ panel willing to take a deferential approach ${ }^{183}$ would likely see these effects as making 'some contribution' to the fulfilment of the objective for the purposes of article 2.2, even though they do not demonstrate changes in consumption or harm.

A respondent member would also be advised to introduce the evidence from prototype alcohol labelling and tobacco labelling ${ }^{184}$ which comes from credible studies, even though it might not be as persuasive as the US evidence, based on real alcohol labels. A panel might nonetheless be prepared to use the evidence, to find that labels bearing the same features as those found in the studies to have an impact — such as graphic imagery, prominent presentation and placement, and regular rotation - make an even greater contribution than the US-style labels to changing drinking behaviour or the relevant intervening variables, and to the ultimate objective of reducing harms from alcohol. A panel may be particularly convinced of the contribution made by warning labels if it considers the member's other alcohol control measures, and the complementary and additive effect of the suite of policies.

\footnotetext{
${ }^{180}$ See, eg, above nn 115, 120, 1415.

${ }^{181}$ Appellate Body Reports, US - COOL, above n 97 [80].

${ }^{182}$ See above nn 20, 21.

${ }^{183}$ See Tania Voon, 'Evidentiary Challenges for Public Health Regulation in International Trade and Investment Law' (2015) 18 Journal of International Economic Law 795, 813.

${ }^{184}$ See above nn $27-31$.
} 


\section{(b) Evidence About the Accuracy of the Content of Warning Labels: Specific Harms}

In addition to debate about whether warning labels can generally reduce harms from alcohol, extensive argument can be expected about the particular content of the warning messages, as discussed in Part III.C.1 above. The argument might be made that specific messages make no contribution to the fulfilment of the objective because they are factually incorrect. If individual messages that are part of the labelling measure are flawed, then the overall contribution of the labelling measure to the objective is accordingly reduced. Thus, a complainant might argue that the labels increase consumer confusion or do not provide 'meaningful information' to consumers, ${ }^{185}$ and cannot improve human health.

In contrast, a charge of factual inaccuracy is unlikely with respect to messages relating to drink driving, drinking during pregnancy, or under-age drinking. The evidence base is too strong now for opposition to messages about drinking and driving, and, as noted above, the major producers have committed to including symbols about this risk on their packaging by $2020 .{ }^{186}$ Similarly, the evidence has developed in the last few years to demonstrate that alcohol use is connected to foetal alcohol spectrum disorder. Much is yet to be discovered about the quantity and the timing of the dose that causes the disability, but the industry has also committed to include the 'pregnant woman' symbol on their packaging. ${ }^{187}$ Further, both warnings are directed to targeted groups - prospective drivers and women during their pregnancies - and, in this sense, do not pose a significant threat to the industry's interest in consumption of alcoholic beverages by the general population.

The arguments against specific warning messages are more likely to arise where they mention cancer or other serious injuries or diseases (as seen in the response to Korea's new warnings). ${ }^{188}$ Again, the evidence about the relationship between alcohol consumption and the specific harm will be important in rebutting an argument of factual inaccuracy. Most of the messages discussed in the TBT Committee include information about harms from alcohol that are supported by mainstream science. For example, evidence of alcohol consumption causing cancer in several sites in the body is now well-established (as discussed in Part I), ${ }^{189}$ but was highly contested in the TBT Committee meetings, and continues to be disputed by parts of the alcohol industry. ${ }^{190}$

\footnotetext{
${ }^{185}$ Cf Appellate Body Reports, US - COOL, above n 97 [473].

${ }^{186}$ Beer Wine Spirits, Providing Consumer Information and Responsible Product Information (2015) Producers' Commitments <http://www.producerscommitments.org/commitments/providing-consumer-information-andresponsible-product-innovation/>.

${ }^{187}$ Ibid.

${ }^{188}$ See above nn 109, 110, 111. See also the response to the Canadian Yukon Territories' warning labels about the risks of cancer from alcohol consumption. Under pressure from the industry, they were removed a few weeks after being introduced: Ian Austen, 'Yukon Government Gives in to Liquor Industry on Warning Label Experiment' The New York Times (online), 6 January 2018 $<$ https://www.nytimes.com/2018/01/06/world/canada/yukon-liquor-alcohol-warnings.html $>$.

${ }^{189}$ See above nn 2-10.

${ }^{190}$ Mark Petticrew et al, 'How Alcohol Industry Organisations Mislead the Public About Alcohol and Cancer' (2018) 37 Drug and Alcohol Review 293. See the industry's contestation of the claims by Petticrew et al, and their response to the industry: John Larsen et al, 'Accuracy of Alcohol and Breast Cancer Risk Information on Drinkaware's Website' (2018) 37 Drug and Alcohol Review 304; Louise Nadeau and Hubert Sacy, 'Educ'alcool response to Petticrew et al: 'How Alcohol Industry Organisations Mislead the Public About Alcohol and Cancer' (2018) 37 Drug and Alcohol Review 307; Marjana Martinic, 'The International Alliance for Responsible Drinking's Response to Petticrew et al: "How Alcohol Industry Organisations Mislead the Public About Alcohol and Cancer"' (2018) 37 Drug and Alcohol Review 308; John Timothy, 'Portman Group Response to Petticrew et al: 'How Alcohol Industry Organisations Mislead the Public About Alcohol and Cancer' (2018) 37 Drug and Alcohol Review 310; Mark Petticrew et al, 'The Strategies of Alcohol Industry SAPROs: Inaccurate Information,
} 
The only warning message discussed in the TBT Committee that seems not to have a basis in evidence is Turkey's message: 'alcohol is not your friend'. It is difficult to know what a panel would make of this type of social marketing hyperbole, which is intentionally not designed to be scientifically accurate; its impact derives from its novelty. Other social marketing campaigns use fear, shock or repulsion to drive behaviour change. ${ }^{191}$ One possibility is that a panel would recognize the marketing device being used and find that the statement made some contribution to the public health objective, but also find that such a statement was a more considerable burden on international trade than a statement based in fact. However, the inclusion of such a statement on a warning label may also be found to make no contribution to the achievement of an objective defined in the manner suggested by the US: to inform people about the risks from consumption of alcohol. The Turkish message arguably does not do this.

\section{(c) Evidence About the Accuracy of the Content of Warning Labels: Causal Links Between any Alcohol Consumption and Harm}

Challenges to the specific wording of messages are also likely to arise where the messages suggest a direct causal link between alcohol consumption and harm, without expressing the link in probabilistic terms (as seen in the challenge to warnings in Korea and Thailand). ${ }^{192}$ Similarly, if warnings suggest that any level of consumption causes harm, rather than excessive or dangerous patterns of consumption, then claims may be made that the warnings lack factual accuracy and are not informing consumers about the real risks. Both objections to the content of warnings tap into the major policy debates about the health benefits (if any) of alcohol, and the vehemently contested issue about the advantages of reducing consumption in the population overall, as a vehicle for reducing harm in accordance with the theory of Kettil Bruun et al, discussed above.

The research evidence will be particularly important in relation to these questions. The risk of many diseases and injuries attributable to alcohol arises at quite low levels of consumption, and not only through 'excessive' consumption as commonly understood. For example, people consuming 1-2 standard drinks per day increase their chance of colorectal and oesophageal cancer by 21 per cent. ${ }^{193}$ Nevertheless, the risks at low levels of consumption may also be low, and there is often a dose-response relationship between consumption and harm. In these circumstances, a panel may therefore accept warnings that simply speak of 'drinking' or 'alcohol' as the source of the problem. Similarly, a panel may well be prepared, if it takes a deferential approach, to accept that warnings expressed in terms of causation are sufficiently supported by the science to be considered correct and not misleading to consumers.

\footnotetext{
Misleading Language and the Use of Confounders to Downplay and Misrepresent the Risk of Cancer' (2018) 37 Drug and Alcohol Review 313.

${ }^{191}$ See eg, the social marketing campaign successfully used to reduce the road toll from drink driving in Victoria, Australia: Reece Hooker, 'Greg Harper, Mastermind Behind Drink Drive, Bloody Idiot' Ads Passes Away', The Age (online), 28 September $2017<\mathrm{http}$ //www.theage.com.au/victoria/greg-harper-mastermind-behind-behinddrink-drive-bloody-idiot-ads-passes-away-20170114-gtrh5i.html>.

${ }^{192}$ See above nn 108-111.

${ }^{193}$ United European Gastroenterology, Alcohol and Digestive Cancers Across Europe: Time for Change (2017) $<$ https://www.ueg.eu/epaper/Alcohol_and_Digestive_Cancers_Across_Europe_Report/>.
} 
Despite claims in TBT Committee meetings that proposed warning labels have 'a limiting effect on trade', ${ }^{194}$ such labels are likely to be seen as producing relatively low levels of trade restrictiveness. A labelling requirement is generally understood as less trade restrictive than, say, an import ban, which is often proposed as an example of the most trade restrictive measure possible. ${ }^{195}$ However, the more extensive a member's prescriptions about the warning, the more trade restrictive the measure becomes, in terms of limiting 'the competitive opportunities' for imported products to access, and compete in, foreign markets. ${ }^{196}$ In particular, to comply with exacting presentation and placement requirements, producers may need to make greater changes to their products to enter a particular domestic market. Further, the concerns raised in the TBT Committee meetings about the rotation requirement, the place of small and medium producers, and products with long shelf life suggest that such requirements may create more barriers to trade. ${ }^{197}$ Given that members seem to be expressing a preference for being able to apply extra required health information on stickers rather than on the main labels, this also seems to be a potential argument about trade restrictiveness where some members, such as India, ${ }^{198}$ refuse to allow this flexibility.

\section{Alternatives}

A complainant member may seek to identify a less trade restrictive alternative to an alcohol labelling requirement, which makes an equivalent contribution to the fulfilment of the measure's objective ${ }^{199}$ and is reasonably available to the respondent member. ${ }^{200} \mathrm{In}$ this context, the respondent's existing measure will not be considered an 'alternative'. ${ }^{201}$ The most obvious alternative to labelling requirements, which has been mentioned in the TBT Committee meeting minutes, is public education or school education to convey information about the risks included on the labels. ${ }^{202}$ As the responsibility for these programs would likely fall on government, they would impose a lesser burden on industry. However, studies of these programs suggest that they are generally not successful in changing behaviour. ${ }^{203}$ Although labels may not make a major contribution to public health by reducing alcohol-related harm, it is unlikely that a panel would find that an education program would make a contribution equivalent to labels. Both labels and education programs seek to inform and, by doing so, change the way people drink, but the proximity of the label to the purchasing and drinking

\footnotetext{
${ }^{194}$ Appellate Body Reports, US - COOL, above n 97 [375]; Appellate Body Report, US — Tuna II (Mexico), above n 97 [319].

${ }^{195}$ See Tania Voon, 'Exploring the Meaning of Trade-restrictiveness in the WTO' (2015) 14 World Trade Review 451, 461 and the cases mentioned therein.

${ }^{196}$ Appellate Body Reports, US - COOL, above n 97 [477].

${ }^{197}$ See above nn 1315, 1326, 1371, 1382.

198 See above n 1482 .

${ }^{199}$ Appellate Body Reports, US - COOL, above n 97 [373]; US - COOL (Article 21.5 - Canada and Mexico), above n 1671 [5.201].

${ }^{200}$ Appellate Body Reports, US - COOL, above n 97 [471]; Appellate Body Report, US — Tuna II (Mexico), above n 97 [322].

${ }^{201}$ Marrakesh Agreement Establishing the World Trade Organization, opened for signature 15 April 1994, 1867 UNTS 3 (entered into force 1 January 1995) annex 1A ('General Agreement on Tariffs and Trade 1994') art XX; Appellate Body Report, Brazil - Retreaded Tyres, above n 97 [172].

${ }^{202}$ See eg, TBT Committee, Minutes of the Meeting 30-31 October 2013, WTO Doc G/TBT/M/ 61 (5 February 2014) [2.38] (EU); TBT Committee, Minutes, WTO Doc G/TBT/M/51, above n 104 [245] (NZ); TBT Committee, Minutes, WTO Doc G/TBT/M/50, above n 104 [5] (EU).

${ }^{203}$ Babor, above n 5, 215.
} 
occasion may give it more impact than educational messages seen or heard in the past or at a different place.

Other alternatives may relate to modified labelling schemes, including industry self-regulatory labelling initiatives, the omission of certain messages, and less onerous presentation, placement or rotation requirements. One possible alternative that would require close examination by a panel would be a suggestion that warnings appear on stickers or supplementary labels, rather than the main label. Many members have called for this option in the TBT Committee. ${ }^{204}$ This may be a less trade restrictive option for producers, as they have the choice of using the same label for all markets and then applying an additional sticker label for a specific market. ${ }^{205}$ No evidence has been developed to date regarding the effectiveness of warnings on stickers or supplementary labels compared to the main label. Such evidence could be crucial in determining whether warnings placed on supplementary labels make an equivalent contribution to warnings positioned on the main label.

\section{Conclusion}

It seems unlikely that a warning scheme that reflects good science about the harms from alcohol and observes the design features suggested by the developing body of reliable evidence would be found inconsistent with article 2.2 of the TBT Agreement. Although warnings might be found to make only a small contribution to reducing harms from alcohol through changing the factors that are significant to changing drinking behaviour, it seems unlikely that education programs or different labelling schemes would be considered good alternatives, particularly given the risks associated with not addressing alcohol-related harm and the gravity of the consequences that can flow from doing so. The one exception to this view is for stickering and supplementary labelling. Placing warnings on supplementary labels, rather than the main label, may be seen as a reasonably available alternative, so that a requirement for warnings to appear on the main label would be found to be unnecessarily restrictive of trade and inconsistent with article 2.2. However, further evidence would be needed to determine whether supplementary labels could make a contribution equivalent to warnings on main labels in promoting health objectives.

\section{Other Health Information Requirements and International Standards: TBT Article 2.4}

Article 2.4 of the TBT Agreement might also be used to challenge a health information labelling measure that did not allow country-specific health information, such as an ingredients list or nutritional information, to be placed on stickers or supplementary labels as opposed to the main label. As discussed above, several members, including the EU and Japan, have argued Codex Standard 1-1985 (Labelling of Pre-packaged Food) is relevant to alcoholic beverage labelling. Under the heading, 'Presentation of Mandatory Information' and the sub-heading, 'Language', clause 8.2 of this standard provides: ${ }^{206}$

8.2.1 If the language on the original label is not acceptable to the consumer for whom it is intended, a supplementary label containing the mandatory information in the required language may be used instead of relabelling.

8.2.2 In the case of either relabelling or a supplementary label, the mandatory information provided shall fully and accurately reflect that in the original label.

\footnotetext{
${ }^{204}$ See eg, above n 144.

${ }^{205}$ See O'Brien et al, Marginalising Health Information, above n 19, 382.

${ }^{206}$ Codex Alimentarius Commission, Standard 1-1985, above n 146, cl 8.2.
} 
Would an alcohol health information labelling regime for an ingredients list or nutritional information that did not comply with Codex Standard 1-1985 be inconsistent with article $2.4 ?^{207}$ Article 2.4 provides:

Where technical regulations are required and relevant international standards exist or their completion is imminent, Members shall use them or the relevant parts of them, as a basis for their technical regulation, except when such international standards or their relevant parts would be an ineffective or inappropriate means for the fulfilment of the legitimate objectives pursued, for instance because of fundamental climatic or geographic factors or fundamental technological problems.

For alcohol health labelling, the critical issues under art 2.4 are whether Codex Standard 11985 is both 'an international standard' that is 'relevant' to the labelling measure and an 'effective' and 'appropriate' means to fulfil the 'legitimate objectives' being pursued by the measure. ${ }^{208}$ Firstly, there seems little doubt that a panel would consider Codex Standard 11985 'an international standard'. A 'standard' is (a) made by a 'recognized body', and (b) compliance is 'not mandatory'. ${ }^{209}$ As to point (a), Codex Standard 1-1985 is made by the Codex Alimentarius Commission ('Commission'), established in 1963, with the Food and Agriculture Organization and the World Health Organization as its parent organisations. ${ }^{210}$ The Commission has 187 member countries and one member organisation, the EU. ${ }^{211}$ The principal task of the Commission is the development of a Codex Alimentarius, which consists of 'international food standards, guidelines and codes of practice [which] contribute to the safety, quality and fairness of [the]...international food trade'. ${ }^{212}$ The Commission clearly accords with the WTO Appellate Body's descriptions of a 'recognized body' as an 'international standardising body' that has 'recognised activities in standardisation' and membership open to all WTO members, ${ }^{213}$ with there being no requirement that standards are made by consensus. ${ }^{214}$ It may also be relevant as context that the Commission is recognized in connection with 'standards' in article 3.4 of the WTO's Agreement on the Application of Sanitary and Phytosanitary Measures ('SPS Agreement'). ${ }^{215}$ As to point (b), compliance with the Commission's standards is entirely voluntary for its members. ${ }^{216}$

\footnotetext{
${ }^{207}$ The Codex Standard is potentially relevant to art 2.2. Art 2.5 provides that 'whenever a technical regulation is prepared, adopted or applied for one of the legitimate objectives explicitly mentioned in [art 2.2], and is in accordance with relevant international standards, it shall be rebuttably presumed not to create an unnecessary obstacle to trade'. It has the effect that a defending member can therefore use 'an international standard' to raise an argument against their measure being inconsistent with art 2.2. For example, a member who requires an ingredients list on packaged alcohol could rely on art 2.5 to argue that, as the Codex Standard provides that food should bear an ingredients list, its measure is not unnecessarily trade restrictive.

${ }^{208}$ See generally Tania Voon and Andrew D Mitchell, 'International Trade Law' in Tania Voon, Andrew D Mitchell and Jonathan Liberman (eds), Regulating Tobacco, Alcohol and Unhealthy Foods: The Legal Issues (Edward Elgar, 2014) 86, 95-8.

${ }^{209}$ TBT Agreement, above n 18, Annex 1.2 'standard'.

${ }^{210}$ Caoimhín MacMaoláin, EU Food Law: Protecting Consumers and Health in a Common Market (Hart Publishing, 2015) 44-5.

${ }^{211}$ World Health Organization and Food and Agriculture Organization of the United Nations, Codex Members and Observers (2018) < http://www.fao.org/fao-who-codexalimentarius/about-codex/members/en/>.

${ }^{212}$ World Health Organization and Food and Agriculture Organization of the United Nations, About Codex (2018) $<$ http://www.fao.org/fao-who-codexalimentarius/about-codex/en/>.

${ }^{213}$ Appellate Body Report, US - Tuna II (Mexico), above n 97 [359], [374]-[375].

${ }^{214}$ TBT Agreement, above n 18, Annex 1, 2 'Standard: Explanatory Note'; Appellate Body Report, EC —Sardines, above n 165 [221]-[227].

${ }^{215}$ Marrakesh Agreement Establishing the World Trade Organization, opened for signature 15 April 1994, 1867 UNTS 3, 33 ILM 1125 (1994) (entered into force 1 January 1995), Annex 1A ('Agreement on the Application of Sanitary and Phytosanitary Measures), 1867 UNTS 493 ('SPS Agreement')) art 3.4.

${ }^{216}$ World Health Organization and Food and Agriculture Organization of the United Nations, About Codex, above n 212 .
} 
However, even if Codex Standard 1-1985 is 'an international standard' for the purposes of article 2.4, the entire standard and the clause cited above are not necessarily 'relevant' to alcohol health information labelling. The WTO Appellate Body has indicated that an international standard is relevant to a technical regulation where it 'bears upon, relates to or is pertinent to' the particular technical regulation. ${ }^{217}$ Codex Standard 1-1985 applies to 'food' and seems to apply to alcoholic beverages. ${ }^{218}$ The general principles underpinning the standard are the prevention of labelling that is false, misleading, or deceptive or that would create 'an erroneous impression regarding [the food's] character'. ${ }^{219}$ It then sets out 'mandatory' labelling requirements for packaged food, including the name of the food, lists of ingredients, net contents and drained weight, name and address of the manufacturer or other person in the food supply chain, country of origin (if omission would mislead or deceive consumers), lot identification, date marking and storage instructions, and instructions for use. ${ }^{220}$ It also provides for quantitative labelling of certain ingredients and declarations as to the treatment of food with ionising radiation. ${ }^{221}$ The standard also includes presentation requirements for the information, including clause 8.2 set out above, as well as requirements about the legibility and visibility of the information. ${ }^{222}$ And it recognises that other 'optional' information may be displayed on pre-packaged food, as long as 'it is not in conflict with the mandatory requirements' of the standard and the general principles. ${ }^{223}$

To the extent that Codex Standard 1-1985 establishes requirements for the listing of ingredients in food and date marking, it may be relevant - in the sense that it 'bears upon, relates to or is pertinent ${ }^{224}$ — to alcohol labelling proposals, such as those by India, that mandate ingredients lists and 'best before' dates. However, the Codex Standard does not speak to other labelling information required by India, such as nutritional information, and therefore cannot be considered 'relevant' to this information. This means that the supplementary labelling rule in clause 8.2 can apply, if at all, only to India's requirement of ingredients lists and best before dates.

But the supplementary labelling standard is worded to cover situations where 'the language on the original label is not acceptable to the consumer for whom it is intended...'. This is not the situation in which WTO members are invoking the standard. They are calling on members such as India to use supplementary labelling generally because it is more beneficial in commercial and trade terms, not because there is a need for a label in a language different from the main label. Arguably, Codex Standard 1-1985 is therefore not relevant to Indian labelling rules regarding alcoholic ingredients lists and best before dates either. If so, India cannot be in breach of article 2.4 .

However, assuming that Codex Standard 1-1985 is relevant to India's measure, its ongoing refusal to allow stickering for ingredients lists and best before dates may place it in breach of article 2.4, unless it can demonstrate that the supplementary labelling rule in Codex Standard

\footnotetext{
${ }^{217}$ Appellate Body Report, EC -Sardines, above n 165 [229] -[230].

${ }^{218}$ Codex Alimentarius Commission, Codex Standard 1-1985, above n 142, cl 2 definition of 'food' which includes 'drinks' and expressly excludes 'tobacco and substances used only as drugs'.

${ }^{219}$ Ibid cl 3.1.

${ }^{220}$ Ibid cl 4. Note, again, that compliance with the standard is not mandatory for members of the Commission, but if members choose to comply with the standard, then there are certain labelling requirements that must be met.

${ }^{221}$ Ibid cl 5.

${ }^{222}$ Ibid cl 8.1.

${ }^{223}$ Ibid cl 7.

${ }^{224}$ See above n 217 and corresponding text.
} 
1-1985 would be 'an ineffective or inappropriate means for the fulfilment of the legitimate objectives pursued'. ${ }^{225}$ The WTO Appellate Body in the EC - Sardines case agreed with the Panel's interpretation in that case that:

An ineffective means is a means which does not have the function of accomplishing the legitimate objective pursued, whereas an inappropriate means is a means which is not specially suited for the fulfilment of the legitimate objective pursued.... The question of effectiveness bears upon the results of the means employed, whereas the question of appropriateness relates more to the nature of the means employed. ${ }^{226}$

The Appellate Body also agreed that the concept of 'legitimate objective' in article 2.4 refers to the same concept in article 2.2. ${ }^{227}$ The onus would be on the complainant to show that Codex Standard 1-1985 on supplementary labels would be an 'effective' and 'appropriate' means, in India, for providing information to consumers to reduce the harms from alcohol. ${ }^{228}$ In reply, India, as the respondent, may use some of the arguments that it has raised in the TBT Committee meetings to make the case that supplementary labels or stickers would be 'ineffective'. These include concerns about 'unscrupulous traders ... manipulating or tampering with the labels ${ }^{229}$ and thereby impeding the achievement of its goal of providing information to consumers. However, its position may be somewhat undermined by the fact that it has recently allowed stickering for some information, including importer details. ${ }^{230}$ If stickers are effective for providing importer information, could they be effective for providing information about ingredient lists and best before dates? India might need additional evidence to shed light on this difference.

Although Codex Standard 1-1985 does not cover all of the types of health information being added to alcoholic beverage labels, including warnings and nutritional information, it does cover some information, such as the name of the food, ingredients list, importer details, and best before dates. At the same time, the standard envisages using stickering to deal with situations where consumers require information in a language different from that used on the main label. This suggests that clause 8.2 of standard 1-1985 is not a relevant standard for the alcoholic beverage labelling matters that have arisen in the TBT Committee, notwithstanding members' invocation of it. Even if it were a relevant standard, local conditions might render supplementary labelling an ineffective or inappropriate method for providing consumer information, so there is no breach of article 2.4 in not using the standard.

\section{CONCLUSION}

The alcoholic beverage industry would certainly prefer that government not regulate alcohol as a commodity, including through labelling. It is in the industry's interests to suggest that the problem 'is in the person' and not 'in the bottle'. ${ }^{231}$ But on the specific issue of health information on alcoholic beverages, the industry does not seem opposed to all labelling measures. Rather, certain features of labelling schemes bother the industry and, in turn, WTO members, and our study has offered the clearest identification of these features to date. The minutes of TBT Committee meetings provide unique insights into what the members - and

\footnotetext{
${ }^{225}$ TBT Agreement, above n 18, art 2.4.

${ }^{226}$ Appellate Body Report, EC - Sardines, above n 165 [285].

${ }^{227}$ Ibid [286].

${ }^{228}$ Ibid [282].

${ }^{229}$ TBT Committee, Minutes, WTO Doc G/TBT/M/64/Rev.1, above n 144 [2.124] (India).

${ }^{230}$ See TBT Committee, Minutes, WTO Doc G/TBT/M/71, above n 107 [2.198].

${ }^{231}$ Robin Room, 'The Long Reaction Against the Wowser: The Prehistory of Alcohol Deregulation in Australia' (2010) 19 Health Sociology Review 151, 157.
} 
the industry - object to about alcohol labelling: the messages that remind us of the serious risks associated with drinking; the graphic pictures accompanying these messages; the insistence on prominent front of container labelling; the frequent rotation of messages; the refusal to allow the information to be relegated to supplementary labels; and the bans on proalcohol marketing messages. None of these features is include in the industry's voluntary labelling schemes.

Although the industry may object to the alcohol labelling schemes being proposed and implemented in countries around the world, our view is that the TBT Agreement will provide little comfort to alcohol exporting members who seek to rely on it to challenge these new labelling measures. That said, the trade law arguments made by exporting members may still have a 'chilling effect' on countries looking for new ways to address alcohol-related harm, but wanting to avoid a potentially costly and difficult international dispute. For countries wanting to innovate in the public health space, they must face the fact that the evidence base is not as strong for alcohol labelling as it is for tobacco. Yet, if measures are designed to reflect the existing evidence, including that relating to prototype alcohol labels and tobacco labelling, we expect that they will not be found to be unnecessarily restrictive of international trade. The main uncertainty remaining is about the refusal of governments to allow stickering or supplementary labelling. Codex Standard 1-1985 on supplementary labelling is not relevant to the measures under consideration in the TBT Committee which therefore do not breach article 2.4. However, further evidence is needed to determine the differential impact of supplementary and main labels with respect to health warnings, which may be relevant to claims under TBT article 2.2. Our future work will also consider how public health alcohol labelling measures will be treated by other parts of international trade and investment law.

The WHO has proposed that the Commission develop a new Codex Alimentarius standard on alcohol health labelling. ${ }^{232}$ The proposal was before the Commission and its Executive Board at their meetings in July 2017, ${ }^{233}$ and was discussed in detail by the Codex Committee on Food Labelling in October 2017. ${ }^{234} \mathrm{~A}$ WHO discussion paper prepared for this Committee suggested that the new work could include: amendments to Codex Standard 1-1985 in relation to a definition of alcoholic beverages, product information, health warnings and restrictions in information and packaging presenting risks to health; amendments to an existing Codex guideline on health and nutrition claims to restrict nutrition labelling and health claims; and the creation of a new Codex guideline for restrictions on information and packaging presenting risks to health. ${ }^{235}$ The WHO envisaged the standard could include guidance about product

\footnotetext{
${ }^{232}$ Codex Alimentarius Commission, 'Joint FAO/WHO Food Standards Programme: Report of the Seventy-third Session of the Executive Committee of the Codex Alimentarius Commission' (Report, No REP17/EXEC2, Food and Agriculture Organization of the United Nations and World Health Organization, 17-22 July 2017); Codex Alimentarius Commission, 'Joint FAO/WHO Food Standards Programme' (Report of the Fortieth Session, REP17/CAC, Food and Agriculture Organization of the United Nations and World Health Organization, August 2017); Codex Alimentarius Commission, 'Joint FAO/WHO Food Standards Programme: Provisional Agenda' (Doc CX/FL 17/44/1, Forty-Fourth Session, Food and Agriculture Organization of the United Nations and World Health Organization, Paraguay, 16-20 October 2017).

233 Codex Alimentarius Commission, Joint FAO/WHO Food Standards Programme: Report of the Seventy-Third Session, above n 237; Codex Alimentarius Commission, Joint FAO/WHO Food Standards Programme: Report of the Fortieth Session, above n 237.

${ }^{234}$ Codex Alimentarius Commission, 'Joint FAO/WHO Food Standards Programme: Discussion Paper on Consideration of Issues Regarding Front-of-pack Nutrition Labelling' (Agenda Item 7, No CX/FL 17/44/7, Food and Agriculture Organization of the United Nations and World Health Organization, September 2017).

235 Codex Alimentarius Commission, 'Joint FAO/WHO Food Standards Programme: Discussion Paper on Alcoholic Beverage Labelling’ (Report, No CX/FL 17/443 Add 1, World Health Organization, September 2017) 4.
} 
information, such as ingredients, alcoholic strength, standard drinks, calories, and allergens. It also suggested that standards about warnings could relate carcinogenicity, intoxicating effects, dependence potential, children and adolescents, and pregnancy. ${ }^{236}$ The WHO suggested a timeline for the work that would lead to the new standards adopted by the Commission in July $2021 .{ }^{237}$ However, the WHO proposal was not accepted by the Committee. This does not mean that the proposal will be abandoned, as there was support from some member states, ${ }^{238}$ but progress may be slower than initially envisaged, with more obstacles along the way.

These changes to Codex standards could be useful to public health policy makers as a source of concrete international support for domestic efforts to introduce warnings and other health information on alcoholic beverage labels. Yet the standard could potentially undermine health objectives (including by creating difficulties for health warnings under article 2.4 of the TBT Agreement) if it ends up being restricted to advising about the risks that the industry is already prepared to acknowledge: drink driving, drinking during pregnancy, and under-age drinking. The evidence supports warnings about other more serious risks too. If such a standard is made and does include a set of accepted warnings, it will also have to be revised regularly to reflect new knowledge about the harms from alcohol. The WHO is driving the proposal for a standard and sees benefits in the proposal from the perspective of advancing implementation of the Global Strategy and addressing the significant harms from alcohol. ${ }^{239}$ Care must be taken to ensure that the standard does not become another means for the industry to resist effective alcohol health information appearing on its products.

\footnotetext{
${ }^{236}$ Ibid 3.

${ }^{237}$ Ibid 6.

${ }^{238}$ Codex Alimentarius Commission, 'Joint FAO/WHO Food Standards Programme: Alcohol Labelling: Comments from India, Norway (supported by Kazakhstan)’ (Agenda Item 3, No FL/44 CRD/4 Add 1, World Health Organization, September 2017).

${ }^{239}$ Ibid.
} 